\title{
9. PETROLOGICAL STUDIES ON DSDP LEG 34 BASALTS: NAZCA PLATE, EASTERN PACIFIC OCEAN ${ }^{1}$
}

\author{
D.R.C. Kempe, Department of Mineralogy, British Museum (Natural History), London, England
}

\begin{abstract}
Fourteen fairly to very fresh samples of oceanic basalt (generally LIL-element-depleted, MORB-type) from DSDP Sites 319, 320, and 321 have been examined. Site 319 basalt is an OL-tholeiite, falling in the olivine tholeiite field; texturally it ranges from glassy and variolitic to hyaloophitic, ophitic, and porphyritic. Phenocrysts, ranging up to $3 \mathrm{~mm}$ in diameter, are of granular pyroxene, plagioclase, and olivine largely, but not entirely, altered to smectite. Site 320 and 321 basalts extend over a finer grained textural range, with phenocrysts rarely exceeding $1 \mathrm{~mm}$; Site 321 has some vesicles. Basalts from both sites are PL-tholeiites, falling in the quartz tholeiite field. Trace elements were determined and, in general, show normal behavior. Microprobe analyses are given of the pyroxene and plagioclase phenocrysts and groundmass phases; the former are all augites, those from Site 319 being more calcic than the others. Plagioclase forms large and small zoned phenocrysts, microphenocrystic laths, and groundmass laths; compositions range between $\mathrm{An}_{82}$ (phenocryst cores) and $\mathrm{An}_{46}$ (groundmass and phenocryst rims). Site 319 plagioclases show the greatest variation and include examples of reverse zoning. $\mathrm{FeO}$ is significantly present in the feldspar, inversely proportional to $\mathrm{CaO}$. None of the basalts is very "primitive" (low FeO*/MgO ratio) but basalt from Site 321 is highly fractionated, FETI-type basalt, remarkably similar to that from Site 256, Leg 26. The close juxtaposition of "primitive" (undifferentiated) or relatively "primitive" with FETI-type basalt, now found in two oceans, is discussed. Differentiation at Site 319 proceeds normally; plotted against depth, $\mathrm{Fe} / \mathrm{Mg}$ and $\mathrm{Ab} / \mathrm{An}$ enrichment occurs upwards. There is evidence of a second type of differentiation, possibly representing variation between successive waves of magma, rather than within each wave.
\end{abstract}

\section{INTRODUCTION AND SCOPE OF PAPER}

Fourteen basalt samples from the Nazca plate (eight from Site 319, two from Site 320, and four from Site 321) were examined in thin section and their bulk chemistry (major, minor, and some trace elements) determined. Electron microprobe analyses were made of phenocryst and groundmass phases (pyroxene and plagioclase) from six of the samples. Special attention was paid to the normative mineralogy and differentiation trends of the rocks; other aspects are described elsewhere in this volume. Leg 34 sites are the most southerly of those in the Pacific Ocean as well as the first from the Nazca plate, but three previous DSDP legs (5, 9 , and 16) have operated nearby in the eastern margin of the Pacific Ocean, where samples were drilled from the Pacific plate.

The rocks from Site 319 are, along with those from Site 257 (from Leg 26), the freshest to be recovered by DSDP. Both reach a maximum sonic velocity $(\mathrm{Vp})$ of

'With analytical contributions from J.C. Bevan, V.K. Din, and R.F. Symes.
$6.5 \mathrm{~km} / \mathrm{sec}$ (Hyndman, 1974; Salisbury and Christensen, this volume).

\section{PETROGRAPHY}

\section{Site 319}

Basalt from Site 319 (Bauer Deep) is sometimes porphyritic and ranges in texture from glassy (Plate 1, Figure 1); variolitic (Plate 1, Figures 1 and 2; Plate 2, Figure 1); and hyaloophitic (Plate 1, Figure 5) to subophitic (Plate 1, Figure 4) and ophitic or diabasic (Plate 1, Figure 3). These textures, which are shown in the plates in order of increasing depth, represent variations in the cooling rate of parts of the five or even eight cooling units recognized; these units are considered more likely to be flows than pillow layers or sills. The textures displayed in these rocks are such that they cannot be described by simple textural terms; those used above are generalizations. However, the textural types reflect a cooling sequence in which the following stages, in which phenocrysts or microphenocrysts may or may not be present, are among the most important:

Glass (sideromelane) or palagonite if hydrated (sometimes vesicular), sometimes less rapidly quenched to become spherulitic or variolitic in which develop 
plumose or sheaf-like varioles of pyroxene, forming in coarser grained varieties subophitic "islands" in residual glass patches (hyaloophitic) or else rocks that are totally subophitic or ophitic (diabasic), sometimes showing embayed plagioclase.

Bunch and LaBorde (this volume) give a full account of all aspects of the petrography of the rocks, and consequently only a summary is given here (Table 1). The rocks studied show a similar range of textures to those collected from a sequence of similar length from Site 257, Leg 26, southern Indian Ocean (Kempe, 1974). The Leg 34 rocks contain fewer large phenocrysts than those of Leg 26 but they are more widely distributed. There are far fewer vesicles and none is filled with the glauconitic mineral, celadonite, although a few grains of this mineral are present in Sample 2-1, 111-114 cm. Apart from Leg 26, celadonite is recorded from Leg 17 (Bass et al., 1973). The rather "runic" texture of Sample $3-1,78-81 \mathrm{~cm}$ is interesting (Plate 1, Figure 3). The plagioclase laths are embayed against apparently earlier formed pyroxene grains, a texture very similar to that noted in one or two or the Leg 26 basalts and elsewhere (Kempe, 1974). The large phenocrysts in Sample 7-1, $121-124 \mathrm{~cm}$ are notable in that fresh olivine patches remain in crystals largely altered to smectite-a feature rare in drilled basalts.

\section{Site 320}

The basalt from Site 320 is thought to occur as pillows or thin flows, forming at least 10 cooling units. Both samples examined are variolitic; the upper contains a few small plagioclase phenocrysts (Table 2). The most notable feature is the morphology of the small laths and microlites of plagioclase; these form stellate bunches, occasionally cruciform groups, and are frequently bifurcate at each end like blunt, double-ended tuning forks (Plate 2, Figure 2). Olivine (always as pseudomorphs) is rarely present in the upper sample and is apparently absent in the lower one.

\section{Site 321}

The sequence of four samples from Site 321, Core 14, thought to come from extrusive units, are all hyaloophitic to subophitic, and, unlike the first two series described, are quite highly vesicular (Table 2). Olivine is notably absent, although the upper three samples contain traces and patches of smectite probably formed from the alteration of olivine. Calcite most commonly fills the vesicles, but some are empty and others contain palagonite or smectite. The Section 3, 7-10 cm sample also contains calcite in patches of mesostasis. Plagioclase laths embayed around preformed granular pyroxene are again present (see Site 319) in Sections 1, 42-45 $\mathrm{cm}$; 3, 7-10 cm; and 4, 7-10 cm: (Plate 2, Figures 5 and 6).

\section{CHEMISTRY}

\section{Methods}

The XRF method of Norrish and Hutton (1969) was used to determine $\mathrm{Si}, \mathrm{Ti}, \mathrm{Al}, \mathrm{Fe}, \mathrm{K}$, and $\mathrm{P}$. The concentrations of other major, minor, and trace elements $(\mathrm{Mg}$,
$\mathrm{Ca}, \mathrm{Na}, \mathrm{Mn}, \mathrm{Be}, \mathrm{Cr}, \mathrm{Ni}, \mathrm{Li}, \mathrm{Cu}, \mathrm{Co}, \mathrm{Zn}, \mathrm{V}, \mathrm{Sr}, \mathrm{Ba}$, and $\mathrm{Rb})$ were determined by atomic absorption spectrophotometry on solutions prepared according to the method of Langmyhr and Paus (1968); calibration curves were obtained from measurements on international standard rocks and synthetic standards. Five trace elements $(\mathrm{Nb}, \mathrm{Zr}, \mathrm{Y}, \mathrm{Pb}$, and $\mathrm{Ga})$ were estimated semiquantitatively by a spectrographic method requiring the visual comparison of the sample spectra with those of synthetic standards. The French and Adams (1972) method served for the determination of ferrous iron with the modification that potassium permanganate replaced ceric sulphate as titrant. $\mathrm{H}_{2} \mathrm{O}^{\rightarrow}$ was measured gravimetrically and $\mathrm{H}_{2} \mathrm{O}^{+}$and $\mathrm{CO}_{2}$ by means of a CHN elemental analyzer (V.K. Din).

\section{Results}

All 14 samples studied (eight from Site 319, two from Site 320, and four from Site 321) have been analyzed. The analyses of basalts from Site 319 (Bauer Deep) are reported in Table 3 and those from the eastern margin of the Nazca plate in Table 4. Most of the rocks are relatively fresh. Using the criteria of Miyashiro et al. (1969), established on dredged rocks, an unweathered abyssal tholeiite usually contains less than $2 \% \mathrm{Fe}_{2} \mathrm{O}_{3}$ and $1.2 \% \mathrm{H}_{2} \mathrm{O}$, and has an $\mathrm{Fe}_{2} \mathrm{O}_{3} / \mathrm{FeO}$ ratio of less than 0.3 . $\mathrm{A}$ few of the rocks satisfy the water requirement, but none is within the $\mathrm{Fe}_{2} \mathrm{O}_{3}$ or iron ratio limits. However, most DSDP basalts are more highly altered or weathered than those from Leg 34, and also those from Leg 26 which are very similar in this context; basalts from Site 257 meet the $\mathrm{Fe}_{2} \mathrm{O}_{3}$ limitation but contain more $\mathrm{H} \mathrm{O}^{-}$(Kempe, 1974). Both holes (257 and 319) yielded sequences of comparable length and have maximum sonic velocities of $6.5 \mathrm{~km} / \mathrm{sec}$. As will be shown below, the Site 321 basalt bears a very close resemblance to that from Site 256 ( $\mathrm{Leg} 26$ ), with average $\mathrm{Fe}_{2} \mathrm{O}_{3}, \mathrm{FeO}$, and $\mathrm{Fe}_{2} \mathrm{O}_{3} / \mathrm{FeO}$ values of 3.78 and $3.40,9.83$ and 9.87 , and 0.38 and 0.34 , respectively (Table 4 ).

Apart from the first two samples from Site 319 (31913-1 and 319A-1-1), which differ from the remainder from this site in their low $\mathrm{TiO}_{2}, \mathrm{FeO}^{*}$, and $\mathrm{P}_{2} \mathrm{O}_{5}$ and high $\mathrm{MgO}$ and $\mathrm{CaO}$ contents, the basalts from each site are fairly homogeneous, especially those from Site 321 . Sample 320B-3-1 basalt is somewhat anomalous in its low $\mathrm{SiO}_{2}$ and high $\mathrm{Al}_{2} \mathrm{O}_{3}$, possibly through alteration, and the same applies, to a lesser extent, to the basalt from Sample 319A-5-1. By analogy with Site 256, homogeneity appears to be a characteristic of this type of Feand Ti-rich basalt. The $\mathrm{SiO}_{2}$ content (Figure 1b) varies between $48.79 \%$ and $51.47 \%$ and all but four lie between $49 \%$ and $50 \%$, thus falling very close to the average figure of $49.50 \%$ (Shido et al., 1971). All are lowalumina basalts, in that none has an $\mathrm{Al}_{2} \mathrm{O}_{3}$ content in excess of ca $16.4 \%$ (Miyashiro et al., 1969). In fact, only two have $\mathrm{Al}_{2} \mathrm{O}_{3}>15 \%$, while Site 321 basalts, like those of Site 256 , average ca $13 \%$. With two or three exceptions, the $\mathrm{Fe}_{2} \mathrm{O}_{3} / \mathrm{FeO}$ ratio is around 0.35 to 0.40 , an average range for fresh DSDP basalts but higher than that for fresh dredged rocks. The total $\mathrm{FeO}^{*}$ values are typical, respectively, for "normal" oceanic basalt (the lower part of Site 319, 11.0\%); fairly "primitive" 
TABLE 1

Summary of Typical Characteristics of Basalt Samples From Site 319, Bauer Deep

\begin{tabular}{|c|c|c|c|c|c|c|c|}
\hline $\begin{array}{l}\text { Sample } \\
\text { (Interval } \\
\text { in } \mathrm{cm} \text { ) }\end{array}$ & Plate & Texture & $\begin{array}{l}\text { Co-ordinates in } \\
\text { olivine or quartz } \\
\text { tholeiite field } \\
\text { (from Table 3) }\end{array}$ & Olivine & Pyroxene & Plagioclase & $\mathrm{Ore}^{\mathrm{a}}$ \\
\hline $\begin{array}{l}319-13-1 \\
77-80\end{array}$ & 1, Figure 1 & Variolitic & $d i_{70.6^{h y}} y_{28.4^{o l}} l_{1.0}$ & $\begin{array}{l}\text { Very rare, small, } \\
\text { totally altered } \\
\text { (?palagonite) }\end{array}$ & Plumose and granular & Laths up to $1 \mathrm{~mm}$ & Skeletal \\
\hline $\begin{array}{l}319 A-1-1 \\
48-51\end{array}$ & - & Hyaloophitic & $q_{0.3^{d i}} 57.8^{h y_{41.9}}$ & $\begin{array}{l}\text { Patches of } \\
\text { ?smectite may be } \\
\text { altered olivine }\end{array}$ & $\begin{array}{l}\text { Sheaf-like and } \\
\text { plumose }\end{array}$ & Laths up to $1 \mathrm{~mm}$ & Skeletal \\
\hline $\begin{array}{l}319 \mathrm{~A}-2-1 \\
111-114\end{array}$ & 1 , Figure 2 & $\begin{array}{l}\text { Coarse } \\
\text { variolitic, } \\
\text { some } \\
\text { phenocrysts }\end{array}$ & $q_{7.2^{d i}} 62.2^{h y} y_{30.6}$ & $\begin{array}{l}\text { Possible patches of } \\
\text { smectite after } \\
\text { olivine }\end{array}$ & $\begin{array}{l}\text { Sheaf-like and } \\
\text { granular; } \\
\text { phenocrysts: } \\
\mathrm{Mg}_{42} \mathrm{Fe}_{17} \mathrm{Ca}_{41} \\
\text { groundmass: } \\
\mathrm{Mg}_{43} \mathrm{Fe}_{14} \mathrm{Ca}_{43}\end{array}$ & $\begin{array}{l}\text { Phenocrysts and } \\
\text { laths up to } 2 \mathrm{~mm} \text { : } \\
\mathrm{An}_{79-46} \\
\text { groundmass: } \\
\mathrm{An}_{48}\end{array}$ & Skeletal \\
\hline $\begin{array}{l}319 \mathrm{~A}-3-1 \\
78-81\end{array}$ & 1, Figure 3 & $\begin{array}{l}\text { Ophitic to } \\
\text { very coarse } \\
\text { hyaloophitic, } \\
\text { somewhat runic } \\
\text { texture, some } \\
\text { phenocrysts }\end{array}$ & $q_{3.4^{d i}}{ }_{55.7^{h y}} 40.9$ & & $\begin{array}{l}\text { Long sheaves, up } \\
\text { to } 1.5 \mathrm{~mm} \text {; } \\
\text { phenocrysts: } \\
\mathrm{Mg}_{45-40} \mathrm{Fe}_{13-21} \\
\mathrm{Ca}_{42-39} \\
\text { groundmass: }{ }_{\mathrm{Mg}_{46} \mathrm{Fe}_{14} \mathrm{Ca}_{40}}\end{array}$ & $\begin{array}{l}\text { Zoned phenocrysts } \\
\text { up to } 2 \mathrm{~mm} \text { : } \\
\text { An } 82-58 \\
\text { embayed laths } \\
\text { over } 2 \mathrm{~mm} \text { long: } \\
\mathrm{An}_{81-48} \\
\text { groundmass: } \\
\mathrm{An}_{62-56}\end{array}$ & Skeletal \\
\hline $\begin{array}{l}319 A-3-5 \\
75-78\end{array}$ & 1, Figure 4 & $\begin{array}{l}\text { Subophitic, } \\
\text { some } \\
\text { phenocrysts }\end{array}$ & $q_{3.0^{d i}} i_{52.0^{h y}} 45.0$ & $\begin{array}{l}\text { Large smectites } \\
(2.5 \mathrm{~mm}) \text { after }\end{array}$ & Granular & $\begin{array}{l}\text { Few phenocrysts } \\
\text { up to } 3 \mathrm{~mm}\end{array}$ & Granular \\
\hline $\begin{array}{l}319 \mathrm{~A}-5-1 \\
20-22\end{array}$ & 1, Figure 5 & $\begin{array}{l}\text { Hyaloophitic, } \\
\text { porphyritic }\end{array}$ & $q_{8.8^{d i}} 67.3^{h y} 23.9$ & $\begin{array}{l}\text { Large smectites } \\
\text { after olivine }\end{array}$ & $\begin{array}{l}\text { Sheaf- and fan-like: } \\
\mathrm{Mg}_{45} \mathrm{Fe}_{14} \mathrm{Ca}_{41}\end{array}$ & $\begin{array}{l}\text { Phenocrysts over } \\
2 \mathrm{~mm}: \mathrm{An}_{81-67} \\
\text { groundmass: } \\
\text { An }_{64}\end{array}$ & Granular \\
\hline $\begin{array}{l}319 A-6-1 \\
93-98\end{array}$ & 1, Figure 6 & $\begin{array}{l}\text { Glassy } \\
\text { (palagonitized) }\end{array}$ & $q_{5.7^{d i}} 64.0^{h y_{30.3}}$ & $\begin{array}{l}\text { Small euhedral } \\
\text { fresh and } \\
\text { altered olivine }\end{array}$ & Rare grains & $\begin{array}{l}\text { Rare phenocrysts } \\
\text { up to } 1 \mathrm{~mm} \\
\text { laths and "pins" }\end{array}$ & $\begin{array}{l}\text { Granules } \\
\text { in glass }\end{array}$ \\
\hline $\begin{array}{l}319 \mathrm{~A}-7-1 \\
121-124\end{array}$ & 2, Figure 1 & $\begin{array}{l}\text { Subvariolitic, } \\
\text { porphyritic, } \\
\text { rare vesicles }\end{array}$ & $q_{10.1^{d i}} 57.5^{h y_{32.4}}$ & $\begin{array}{l}\text { Large phenocrysts } \\
\text { (over } 2 \mathrm{~mm} \text { ) partly } \\
\text { but not entirely } \\
\text { altered to smectite }\end{array}$ & $\begin{array}{l}\text { Mostly granular, } \\
\text { some sheaf-like, } \\
\text { very small micro- } \\
\text { phenocrysts; } \\
\text { groundmass: } \\
\mathrm{Mg}_{40} \mathrm{Fe}_{20} \mathrm{Ca}_{40}\end{array}$ & $\begin{array}{l}\text { Few small } \\
\text { Phenocrysts }(1 \mathrm{~mm}) \text { : } \\
\text { An }_{68} \\
\text { groundmass: } \\
\text { An }_{80-66}\end{array}$ & $\begin{array}{l}\text { Granules } \\
\text { in glass }\end{array}$ \\
\hline
\end{tabular}

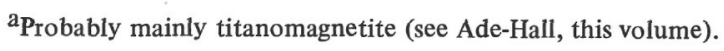

tholeiite (the upper part of Site $319,8.8 \%$, and Site 320 , $8.5 \%$ ); and fractionated, FETI-type (Fe- and Ti-rich) tholeiite (Site 321, 13.2\%). The values for $\mathrm{MnO}$ and $\mathrm{MgO}$ are in no way remarkable; the Site 321 basalts, predictably, contain slightly higher $\mathrm{MnO}$ and lower $\mathrm{MgO}$. In the case of $\mathrm{CaO}$, only the very high values for the upper part of Site 319 are notable. The alkalis show no unusual features, falling well within the range for $\mathrm{Na}_{2} \mathrm{O}$ of $2.5 \%$ to $3.1 \%$ and for $\mathrm{K}_{2} \mathrm{O}$ of $<0.3 \%$ (Shido et al., 1971). Two basalts from Site 319 have slightly higher $\mathrm{K}_{2} \mathrm{O}$ than this, while those from Site 321 contain the least; none from Leg 34 has the exceptionally low $\mathrm{K}_{2} \mathrm{O}$ content of basalts from Sites 14 and 18, Leg 3 (Frey et al., 1974) or even Site 257. $\mathrm{TiO}_{2}$ and $\mathrm{P}_{2} \mathrm{O}_{5}$ values are unremarkable, both reaching their highest levels in Site 321 basalt and their lowest in the "primitive" upper part of Site 319.

Thus the Leg 34 basalts have major and minor element compositions typical of LIL-element (large-ion lithophile)-depleted tholeiites, of MORB-type (midocean ridge basalt) (Christensen et al., 1973). The $\mathrm{Mg} /(\mathrm{Mg}+\mathrm{Fe})$ ratios of Sites 319 and 320 basalt (mean values, 0.54 and 0.59$)$ are typical: that of Site $321(0.45)$ indicates extreme fractionation, discussed in a later section. The low $\mathrm{Cr}$ and $\mathrm{Ni}$ (and $\mathrm{Co}$ and $\mathrm{Cu}$ ) contents of Site 321 basalt, accompanied by high V (and Zn), correlate with this degree of fractionation, as at Site 256 (Figure 1). Similarly, low $\mathrm{Al}_{2} \mathrm{O}_{3}$ is accompanied by low $\mathrm{CaO}$ and thus by low $\mathrm{Sr}$, although, surprisingly, $\mathrm{Sr}$ was not correlated with $\mathrm{CaO}$ and $\mathrm{Al}_{2} \mathrm{O}_{3}$ at Sites 256 and 257 (Kempe, 1974, Table 5). However, $\mathrm{Sr}$ is anomalous in that it is a typical LIL-element, depleted in "primitive" or primary MORB-type tholeiite, but also usually correlates with $\mathrm{Al}_{2} \mathrm{O}_{3}$, which is depleted by fractionation in FETI-type basalts at, for example, Sites 32 (Melson, 1973), 256, and 321 (but see Figure 2). Other elements less noticeably enriched with fractionation are $\mathrm{Ga}, \mathrm{Zr}$, and $\mathrm{Y}$; this is illustrated by comparison of the values 
TABLE 2

Summary of Typical Characteristics of Basalt Samples from Sites 320 and 321, Eastern Margin of the Nazca Plate

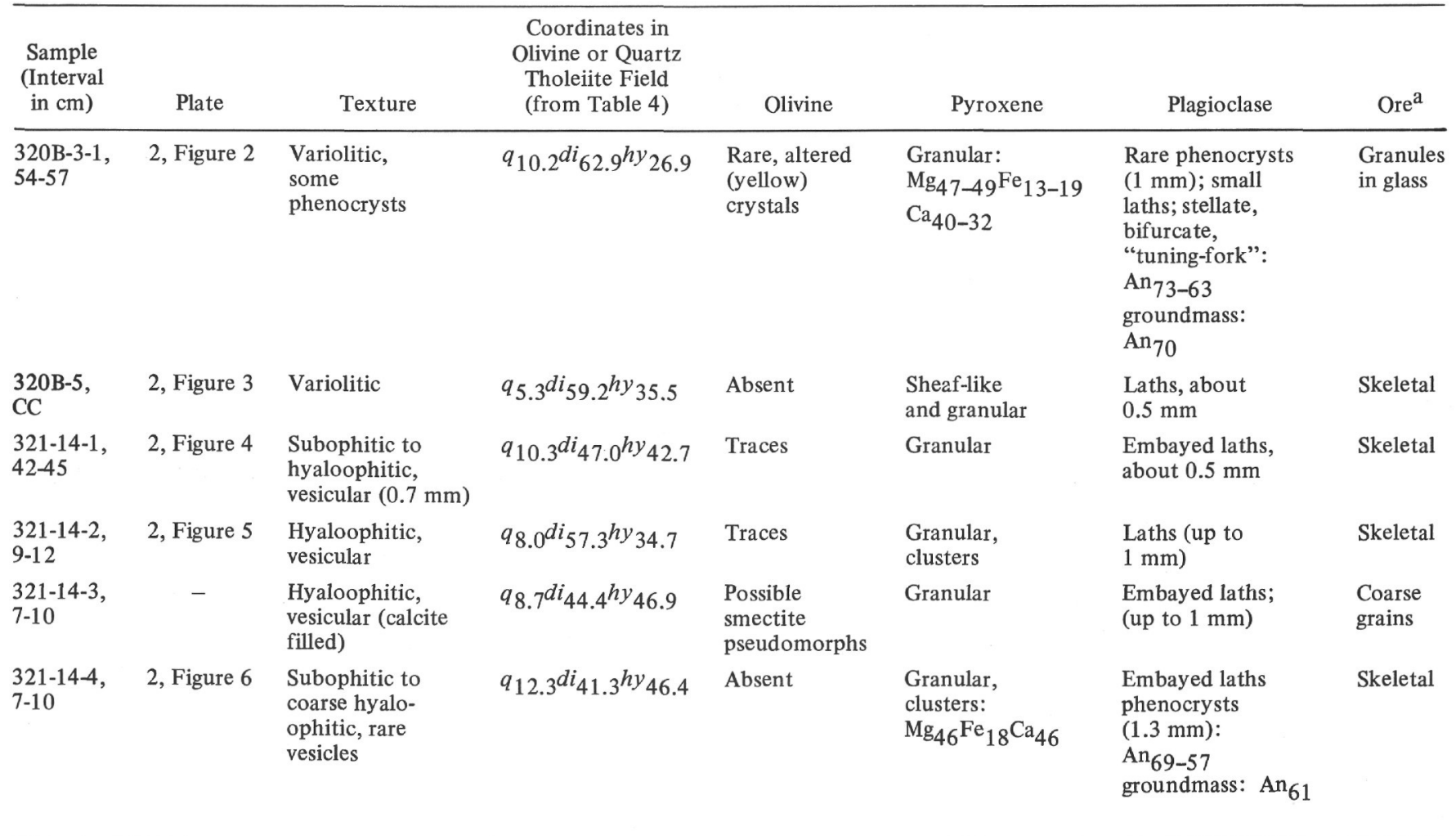

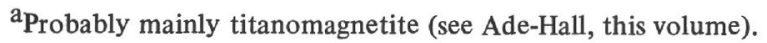

from Site 257 with those from Site 256 and all Leg 34 sites. The low concentrations of the LIL-elements $(\mathrm{Rb}$, $\mathrm{Sr}, \mathrm{Ba}, \mathrm{Y}, \mathrm{Zr}$ ) in the basalts from all three Leg 34 sites are generally typical of MORB basalt; other than the low strontium at Site 321 , only the rather high $\mathrm{Rb}$ and $\mathrm{Ba}$ at Site 319 call for comment. Plotted on the Ti/100$\mathrm{Zr}-\mathrm{Sr} / 2$ diagram of Pearce and Cann (1973), all the Leg 34 basalts fall in the OFB (ocean-floor basalt) field.

In Table 5 some comparative average analyses are given. The Site 319 basalt most closely resembles the average of 13 analyses of Leg 16 basalts, also from the eastern Pacific Ocean (Yates et al., $1973 \mathrm{a}, \mathrm{b}$ ), and that of 18 analyses from the Juan de Fuca and Gorda ridges (Kay et al., 1970). The Site 320 basalt resembles the average for 10 tholeiites from the East Pacific Rise and the Chile Rise (Hekinian, 1971), except that the Leg 34 rock has less iron. It also resembles the average oceanic tholeiite of Engel et al. (1965) except that it is low in $\mathrm{Al}_{2} \mathrm{O}_{3}$. Finally, the Site 321 basalt average can only be compared with a similar rock such as that from Site 256 , Leg 26. The ferrobasalts from the Mid-Atlantic Ridge are similar in iron content, but usually contain less $\mathrm{SiO}_{2}$ and more $\mathrm{Al}_{2} \mathrm{O}_{3}$ (Bald Mountain, $45^{\circ} \mathrm{N}$ : Aumento and Loncarevic, 1969) or more $\mathrm{CaO}\left(53^{\circ} \mathrm{N}\right.$ : Hekinian and Aumento, 1973). What is truly remarkable is the homogeneity of the DSDP FETI basalts (Sites 256, 321, and even 32) at and between each site. It may be that the average compositions for drilled basalts at varying stages of fractionation and from different tectonic settings will prove to be significantly different from the compositional averages for dredged rocks.

\section{Normative Mineralogy and Classification}

The basalts have been plotted in the Yoder and Tilley (1962) projection Ne-Di-Ol-Hy-Q, normalized on a $c c-$ free, $\mathrm{Fe}_{2} \mathrm{O}_{3}=1.50 \%$ basis (Table 6 and Figure 3). The Site 319 basalt is an olivine tholeiite, the average containing $10 \% \mathrm{ol}$. One analysis of the Site 320 basalt contains $o l$, but the other sample and the average for this site, unlike the "primitive" upper part of the Site 319 basalt, as well as the Site 321 basalt, all plot in the q-di$h y$ field. The pair 320 and 321 thus resemble in some respects the pair 256 and 257 from Leg 26; both pairs represent "primitive" (257) or relatively "primitive" (320), and highly fractionated quartz tholeiites closely juxtaposed within the same geomorphological feature. They provide further evidence that there is a strong tendency for drilled basalt to be less olivine normative or even distinctly quartz normative when compared with dredged basalt (Kempe, 1974; 1975).

Although these are low-alumina basalts in the sense of Miyashiro et al. (1969), all of the Leg 34 rocks plot in the high $\mathrm{Al}_{2} \mathrm{O}_{3}$ field in the alkalis $\left(\mathrm{Na}_{2} \mathrm{O}+\mathrm{K}_{2} \mathrm{O}\right)$ versus $\mathrm{SiO}_{2}$ diagram of Kuno (1960). Basalt from Site 319 is an OLtholeiite (Miyashiro et al., 1970; Shido et al., 1971), as would be expected from its modal and normative com- 
TABLE 3

Chemical Analysis of Olivine Tholeiites From Site 319, Bauer Deep ${ }^{a}$

\begin{tabular}{|c|c|c|c|c|c|c|c|c|}
\hline \multicolumn{9}{|c|}{ Sample (Interval in $\mathrm{cm}$ ) } \\
\hline & 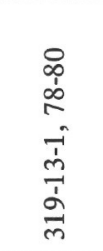 & 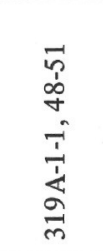 & 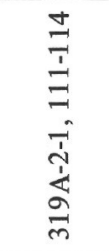 & 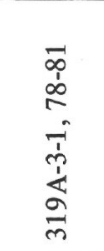 & 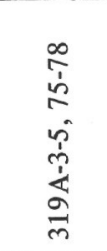 & 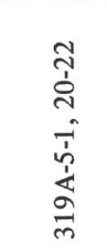 & 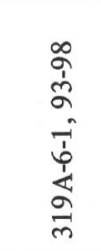 & 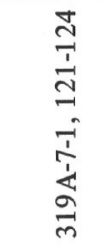 \\
\hline $\mathrm{SiO}_{2}$ & 50.56 & 50.15 & 49.44 & 49.89 & 49.60 & 48.79 & 49.54 & 49.52 \\
\hline $\mathrm{TiO}_{2}$ & 1.22 & 1.20 & 2.01 & 2.11 & 2.00 & 2.00 & 1.90 & 1.83 \\
\hline $\mathrm{Al}_{2} \mathrm{O}_{3}$ & 15.38 & 14.78 & 14.09 & 14.34 & 14.42 & 14.44 & 14.41 & 14.29 \\
\hline $\mathrm{Fe}_{2} \mathrm{O}_{3}$ & 2.55 & 2.59 & 5.07 & 3.10 & 2.94 & 6.33 & 4.24 & 5.20 \\
\hline $\mathrm{FeO}$ & 5.79 & 7.32 & 6.92 & 8.27 & 8.34 & 5.23 & 6.76 & 5.96 \\
\hline $\mathrm{MnO}$ & 0.17 & 0.17 & 0.18 & 0.17 & 0.17 & 0.20 & 0.18 & 0.18 \\
\hline $\mathrm{MgO}$ & 7.41 & 7.95 & 6.51 & 6.67 & 6.97 & 6.55 & 6.56 & 7.09 \\
\hline $\mathrm{CaO}$ & 13.35 & 12.29 & 11.04 & 11.03 & 10.90 & 11.16 & 11.49 & 11.15 \\
\hline $\mathrm{Na}_{2} \mathrm{O}$ & 2.74 & 2.51 & 2.93 & 2.95 & 2.81 & 3.04 & 2.75 & 2.71 \\
\hline $\mathrm{K}_{2} \mathrm{O}$ & 0.11 & 0.05 & 0.25 & 0.12 & 0.11 & 0.32 & 0.35 & 0.18 \\
\hline $\mathrm{H}_{2} \mathrm{O}^{+}$ & 0.43 & 0.59 & 0.66 & 0.65 & 0.66 & 1.19 & 0.70 & 0.88 \\
\hline $\mathrm{H}_{2} \mathrm{O}^{-}$ & 0.56 & 0.55 & 0.93 & 0.70 & 0.74 & 1.06 & 0.85 & 0.75 \\
\hline $\mathrm{P}_{2} \mathrm{O}_{5}$ & 0.08 & 0.08 & 0.18 & 0.20 & 0.17 & 0.16 & 0.17 & 0.17 \\
\hline $\mathrm{CO}_{2}$ & 0.24 & 0.23 & 0.18 & 0.25 & 0.27 & 0.33 & 0.10 & 0.27 \\
\hline Total & 100.59 & 100.46 & 100.39 & 100.45 & 100.10 & 100.80 & 100.00 & 100.18 \\
\hline
\end{tabular}

Trace Elements (ppm)

$\begin{array}{lrrrrrrrr}\mathrm{Ti} & 7,314 & 7,194 & 12,050 & 12,649 & 11,990 & 11,990 & 11,391 & 10,971 \\ \mathrm{Be} & <1 & 1 & 1 & 1 & 2 & 2 & 1 & 1 \\ \mathrm{Ga} & 40 & 40 & 50 & 50 & 50 & 50 & 50 & 50 \\ \mathrm{Cr} & 255 & 255 & 230 & 230 & 235 & 225 & 245 & 240 \\ \mathrm{Li} & 9 & 7 & 9 & 13 & 11 & 30 & 8 & 8 \\ \mathrm{Nb} & <50 & <50 & <50 & <50 & <50 & <50 & <50 & <50 \\ \mathrm{Ni} & 50 & 115 & 70 & 50 & 60 & 100 & 100 & 50 \\ \mathrm{Co} & 85 & 85 & 100 & 90 & 95 & 65 & 70 & 65 \\ \mathrm{Cu} & 95 & 15 & 30 & 15 & 15 & 70 & 65 & 25 \\ \mathrm{~V} & 335 & 310 & 355 & 355 & 325 & 390 & 375 & 325 \\ \mathrm{Zn} & 70 & 80 & 85 & 90 & 85 & 80 & 80 & 80 \\ \mathrm{Zr} & 120 & 150 & 200 & 200 & 200 & 200 & 200 & 200 \\ \mathrm{Y} & 25 & 25 & 50 & 50 & 50 & 50 & 75 & 75 \\ \mathrm{Sr} & 115 & 100 & 115 & 115 & 115 & 135 & 115 & 105 \\ \mathrm{Ba} & 40 & 50 & 40 & 30 & <30 & <30 & <30 & <30 \\ \mathrm{Rb} & <5 & <5 & 9 & <5 & <5 & 7 & 5 & <5 \\ \mathrm{~Pb} & <5 & <5 & <5 & <5 & <5 & \text { n.d. } & \text { n.d. } & <5\end{array}$

\begin{tabular}{lrrrrrrrr}
$q$ & - & 0.13 & 2.58 & 1.31 & 1.16 & 2.82 & 2.11 & 3.68 \\
or & 0.65 & 0.30 & 1.48 & 0.71 & 0.65 & 1.89 & 2.07 & 1.06 \\
$a b$ & 23.18 & 21.24 & 24.79 & 24.96 & 23.78 & 25.72 & 23.27 & 22.93 \\
$a n$ & 29.35 & 28.92 & 24.56 & 25.54 & 26.41 & 24.82 & 25.95 & 26.30 \\
$d i$ & 27.99 & 24.34 & 22.37 & 21.37 & 20.19 & 21.54 & 23.56 & 20.83 \\
$h y$ & 11.28 & 17.66 & 11.03 & 15.68 & 17.44 & 7.66 & 11.13 & 11.73 \\
$o l$ & 0.40 & - & - & - & - & - & - & - \\
$m t$ & 3.70 & 3.75 & 7.35 & 4.49 & 4.26 & 9.18 & 6.15 & 7.54 \\
$i l$ & 2.32 & 2.28 & 3.82 & 4.01 & 3.80 & 3.80 & 3.61 & 3.48 \\
$a p$ & 0.19 & 0.19 & 0.42 & 0.47 & 0.40 & 0.38 & 0.40 & 0.40 \\
$c c$ & 0.55 & 0.52 & 0.41 & 0.57 & 0.61 & 0.75 & 0.23 & 0.61 \\
$\mathrm{FeO} * /$ & 1.09 & 1.21 & 1.76 & 1.66 & 1.58 & 1.67 & 1.61 & 1.50 \\
$\mathrm{MgO}$ & & & & & & & & \\
\hline
\end{tabular}

analyst: V.K. Din.

$\mathrm{b}_{\text {n.d. }}=$ not detected. 
TABLE 4

Chemical Analyses of Quartz Tholeiites From the Eastern Margin of the Nazca Plate ${ }^{a}$

\begin{tabular}{|c|c|c|c|c|c|c|}
\hline \multicolumn{7}{|c|}{ Sample (Interval in $\mathrm{cm}$ ) } \\
\hline & 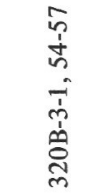 & $\begin{array}{l}\text { ठ } \\
\text { مी } \\
\tilde{\tilde{N}} \\
\text { ले }\end{array}$ & 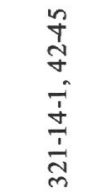 & 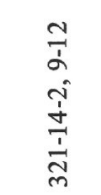 & $\begin{array}{l}\frac{0}{1} \\
\hat{i} \\
\frac{\dot{I}}{\dot{1}} \\
\frac{m}{m}\end{array}$ & 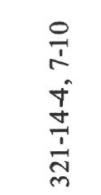 \\
\hline $\mathrm{SiO}_{2}$ & 49.47 & 51.47 & 49.69 & 49.20 & 49.16 & 49.87 \\
\hline $\mathrm{TiO}_{2}$ & 1.54 & 1.85 & 2.43 & 2.39 & 2.42 & 2.40 \\
\hline $\mathrm{Al}_{2} \mathrm{O}_{3}$ & 16.10 & 14.83 & 13.14 & 12.96 & 13.08 & 13.18 \\
\hline $\mathrm{Fe}_{2} \mathrm{O}_{3}$ & 4.41 & 2.49 & 3.88 & 3.60 & 3.83 & 3.81 \\
\hline $\mathrm{FeO}$ & 4.53 & 6.26 & 10.11 & 9.58 & 9.71 & 9.90 \\
\hline $\mathrm{MnO}$ & 0.14 & 0.18 & 0.23 & 0.22 & 0.18 & 0.18 \\
\hline $\mathrm{MgO}$ & 6.21 & 7.37 & 6.20 & 6.12 & 6.43 & 6.20 \\
\hline $\mathrm{CaO}$ & 11.78 & 11.64 & 10.19 & 11.19 & 9.66 & 9.57 \\
\hline $\mathrm{Na}_{2} \mathrm{O}$ & 2.82 & 2.85 & 2.54 & 2.52 & 2.76 & 2.64 \\
\hline $\mathrm{K}_{2} \mathrm{O}$ & 0.22 & 0.23 & 0.14 & 0.11 & 0.16 & 0.12 \\
\hline $\mathrm{H}_{2} \mathrm{O}^{+}$ & 1.45 & 0.69 & 0.59 & 0.67 & 0.87 & 1.10 \\
\hline $\mathrm{H}_{2} \mathrm{O}^{-}$ & 1.39 & 0.45 & 0.47 & 0.58 & 1.25 & 1.12 \\
\hline $\mathrm{P}_{2} \mathrm{O}_{5}$ & 0.14 & 0.19 & 0.24 & 0.25 & 0.25 & 0.23 \\
\hline $\mathrm{CO}_{2}$ & 0.28 & 0.10 & 0.19 & 1.29 & 0.33 & 0.30 \\
\hline Total & 100.48 & 100.60 & 100.04 & 100.68 & 100.09 & 100.62 \\
\hline
\end{tabular}

Trace Elements (ppm)

$\begin{array}{lrrrrrr}\mathrm{Ti} & 9,232 & 11,091 & 14,568 & 14,328 & 14,508 & 14,388 \\ \mathrm{Be} & 1 & 1 & 1 & <1 & 1 & 1 \\ \mathrm{Ga} & 50 & 40 & 50 & 50 & 50 & 50 \\ \mathrm{Cr} & 330 & 220 & 130 & 125 & 125 & 130 \\ \mathrm{Li} & 40 & 11 & 9 & 14 & 13 & 11 \\ \mathrm{Nb} & <50 & <50 & <50 & <50 & 100 & <50 \\ \mathrm{Ni} & 150 & 90 & 50 & 40 & 40 & 50 \\ \mathrm{Co} & 75 & 80 & 65 & 60 & 65 & 60 \\ \mathrm{Cu} & 80 & 75 & 30 & 20 & 15 & 30 \\ \mathrm{~V} & 310 & 325 & 470 & 460 & 420 & 455 \\ \mathrm{Zn} & 70 & 90 & 110 & 110 & 110 & 105 \\ \mathrm{Zr} & 150 & 200 & 200 & 200 & 200 & 200 \\ \mathrm{Y} & 75 & 75 & 60 & 50 & 50 & 50 \\ \mathrm{Sr} & 125 & 140 & 90 & 100 & 90 & 90 \\ \mathrm{Ba} & 30 & <30 & <30 & 30 & <30 & <30 \\ \mathrm{Rb} & <5 & <5 & <5 & <5 & <5 & <5 \\ \mathrm{~Pb} & \text { n.d. }{ }^{\text {b }} & <5 & <5 & \text { n.d. }{ }^{\text {b }} & \text { n.d. }{ }^{\text {b }} & <5\end{array}$

\begin{tabular}{lcrrrrr} 
& \multicolumn{7}{c}{ Norms } \\
$q$ & 3.22 & 2.07 & 4.26 & 4.95 & 3.42 & 4.97 \\
or & 1.30 & 1.36 & 0.83 & 0.65 & 0.95 & 0.71 \\
$a b$ & 23.86 & 24.11 & 21.49 & 21.32 & 23.35 & 22.34 \\
$a n$ & 30.63 & 27.00 & 24.04 & 23.73 & 22.83 & 23.76 \\
$d i$ & 19.86 & 23.19 & 19.47 & 18.01 & 17.47 & 16.64 \\
$h y$ & 8.49 & 13.94 & 17.66 & 17.49 & 18.47 & 18.68 \\
ol & - & - & - & - & - & - \\
$m t$ & 6.39 & 3.61 & 5.63 & 5.22 & 5.55 & 5.52 \\
il & 2.92 & 3.51 & 4.61 & 4.54 & 4.60 & 4.56 \\
ap & 0.33 & 0.45 & 0.57 & 0.59 & 0.59 & 0.54 \\
$c c$ & 0.64 & 0.23 & 0.43 & -2.93 & 0.75 & 0.68 \\
FeO*I & & & & & & \\
$\mathrm{MgO}$ & 1.37 & 1.15 & 2.19 & 2.09 & 2.05 & 2.15 \\
\hline
\end{tabular}

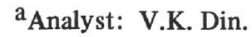

$\mathrm{b}_{\mathrm{n}, \mathrm{d} \text {. not detected. }}$ positions (Tables 1, 3, and 6), although two analyses plot on the boundary (cotectic) curve; the Site 320 and 321 basalts plot as PL-tholeiites (Figure 4), even though fresh olivine was found in other samples from both these holes, as are those from Sites 257 and 256. When fresh, all the basalts from Sites 319, 320, and 321 plot as pyroxene-tholeiites in the system of Hekinian and Aumento (1973), although when altered they may fall within the plagioclase-tholeiite field (Figure 5). Again, the Site 321 basalts plot in positions almost identical to those from Site 256.

It is interesting to compare the Leg 34 basalts with those from Leg 26. Those from Sites 321 and 256 are virtually identical. The Site 320 basalt seems to be intermediate between the Site 256 and 257 basalts in some respects, but in others lies between 257 and 251, the latter being a typical and very fresh spreading ridge quartz tholeiite from the Southwest Branch of the MidIndian Ocean Ridge. Most interesting of all, Site 319 basalt, a slightly undersaturated olivine tholeiite, very closely resembles the Site 251 quartz tholeiite in almost all chemical respects, but bears no resemblance at all to the very mildly alkaline, strongly undersaturated olivine tholeiite from Site 250, in the Mozambique Basin (Kempe, 1974), which is probably of the transitional LIL-element- and REE-enriched (rare-earth element) type of DSDP olivine tholeiite (Christensen et al., 1973). The Site 319 basalt thus has no clear analogy among the Leg 26 rocks, nor does the Site 250 basalt in Leg 34 . Comparisons with Leg 16 basalts indicate that the average for those basalts is a PL-tholeiite close to the Site 320 basalt (Figure 4), and a pyroxene-tholeiite falling within the Site 319-320 cluster (Figure 5); it is very similar indeed to the Site 251 basalt from the Indian Ocean.

\section{Crystallization Differentiation}

The Leg 34 basalts have been plotted in several ways to show their degree of fractionation in comparison with basalts from other sites. In Figure 6a, the FMA diagram shows the basalts from the three sites to have a slightly more restricted range than those from Leg 26. Site 321 basalts again fall in an identical position to those from Site 256, and the Site 319 and 320 basalts fall between this point and the average for Site 257. The average for the Leg 16 basalts (Yeats et al., 1973a,b) lies within the Site 319 cluster. Similarly, the inset Figure 6b shows a tight cluster in the lime-alkalis diagram, with the Leg 16 average falling within it.

The two parameters, $\mathrm{Mg} / \mathrm{Fe}^{*}$ and $\mathrm{Ab} / \mathrm{An}$, are combined in Figure 7 in a fractionation diagram. The main group of Site 319 basalts, covering up to eight cooling units, shows a clear trend practically along the generalized direction. Trends for Sites 163 (eastern Pacific Ocean), 146 (Caribbean Sea), and 256 and 257 (Wharton Basin, southern Indian Ocean) are also shown. If these trends are shown plotted against depth below sedimentbasalt contact (Figures 8,9, and 10), and assuming that all the basalts (except at Site 146) are flows and not sills, some interesting features emerge. Sites 319,163 , and 146 show "normal" trends, with enrichment in iron and alkalis upwards, while Sites 256 and 257 -a series of 


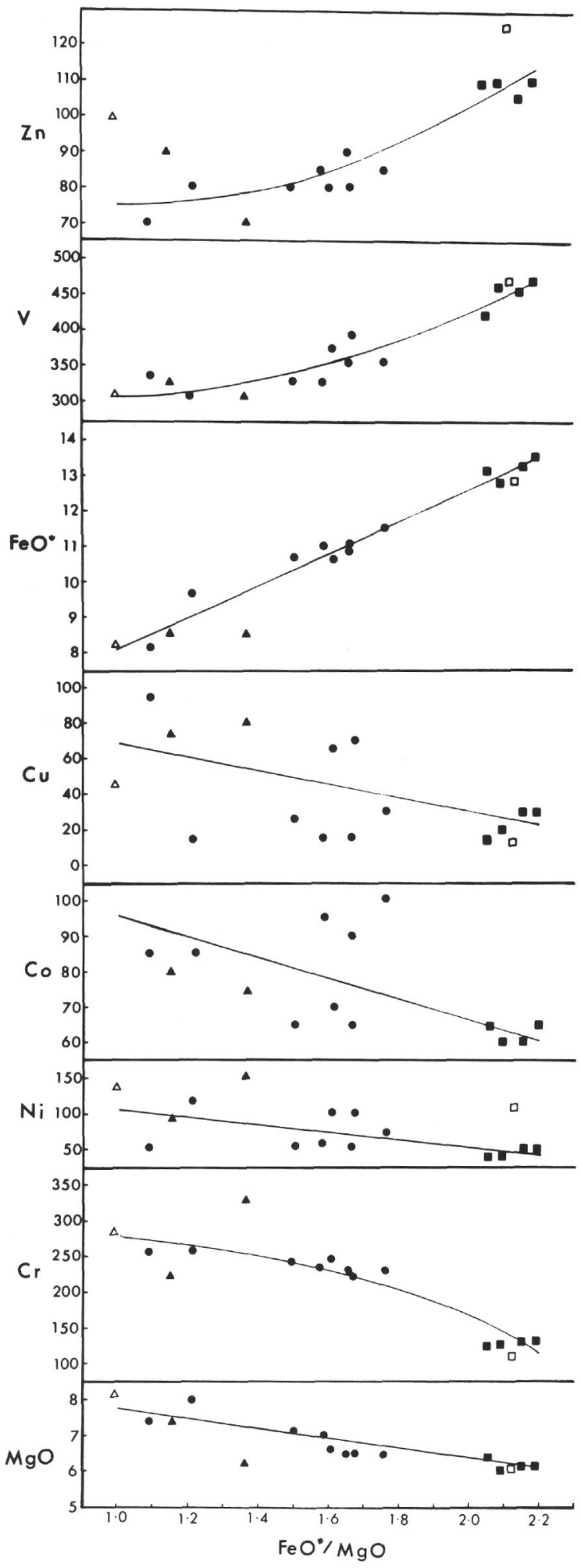

Figure 1a. Major and minor (wt\%) and trace (ppm) elements plotted against $\mathrm{FeO} * \mathrm{MgO}$ ratio for the Leg 34 basalts. Transition and other elements tending to increase or decrease with $\mathrm{Fe} / \mathrm{Mg}$ variation.

seven or eight or more flows-are, in different ways, anomalous (Kempe, 1974; 1975). However, the points at

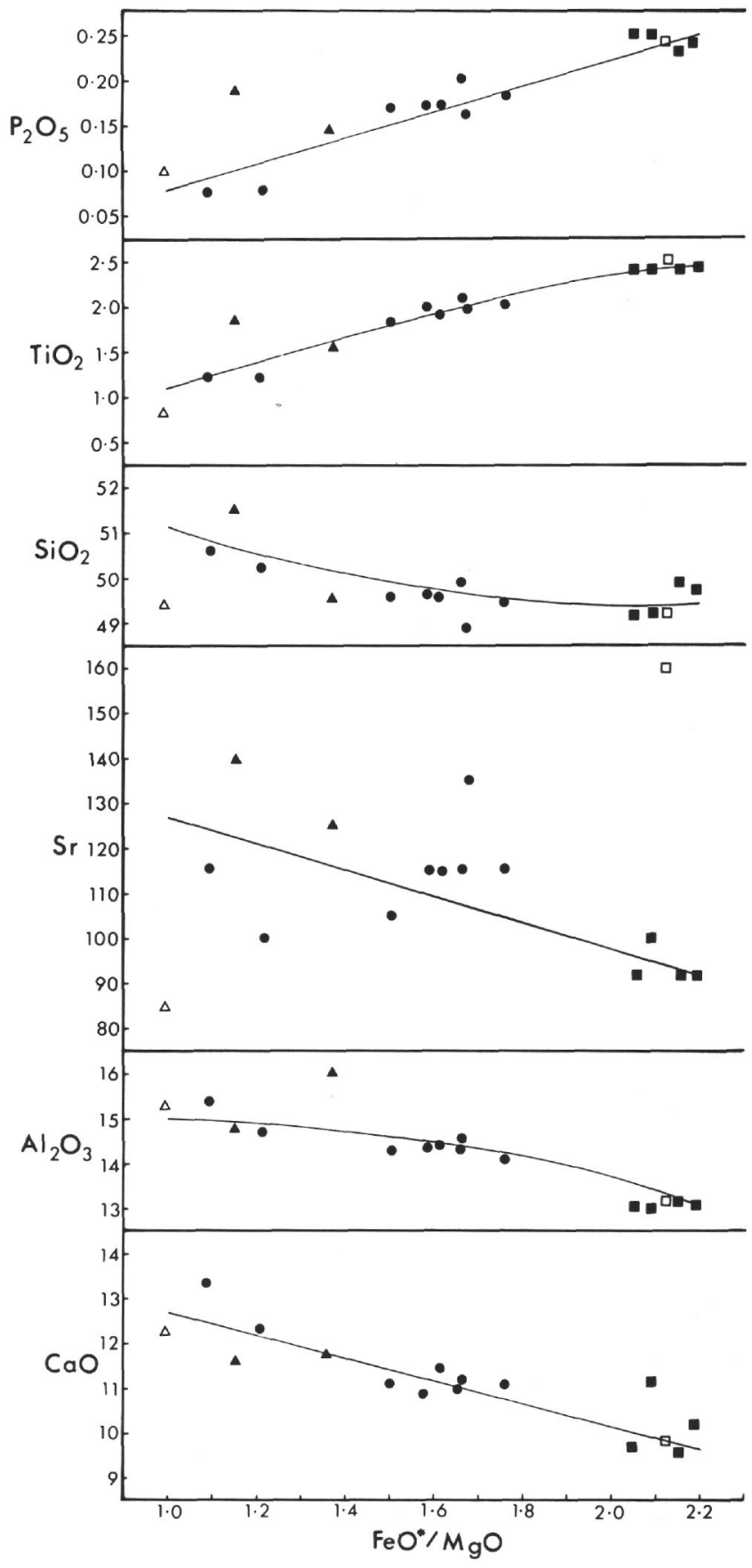

Figure $1 \mathrm{~b}$. $\mathrm{TiO}_{2}$ and $\mathrm{P}_{2} \mathrm{O}_{5} ; \mathrm{Al}_{2} \mathrm{O}_{3}, \mathrm{CaO}$ and $\mathrm{Sr}$; and $\mathrm{SiO}_{2}$. Symbols as follows: - Site 319; $\Delta$ Site 320; - Site 321; $\triangle$ Site 257 ("primitive"); $\square$ Site 256 (FETI-type). The latter two symbols = average compositions of the basalts from the southern Wharton Basin, southeastern Indian Ocean (Kempe, 1974).

Site 163, although thought on the evidence of the glassy selvages to represent seven flow units (Yeats et al., 1973a,b), are in effect only two, separated by a recovery gap (void), while those at Site 146 are an intrusive dolerite sill (Donnelly et al., 1973). At Site 319, the two uppermost samples (319-13-1 and 319A-1-1), which have been approximately equated allowing for the 13 


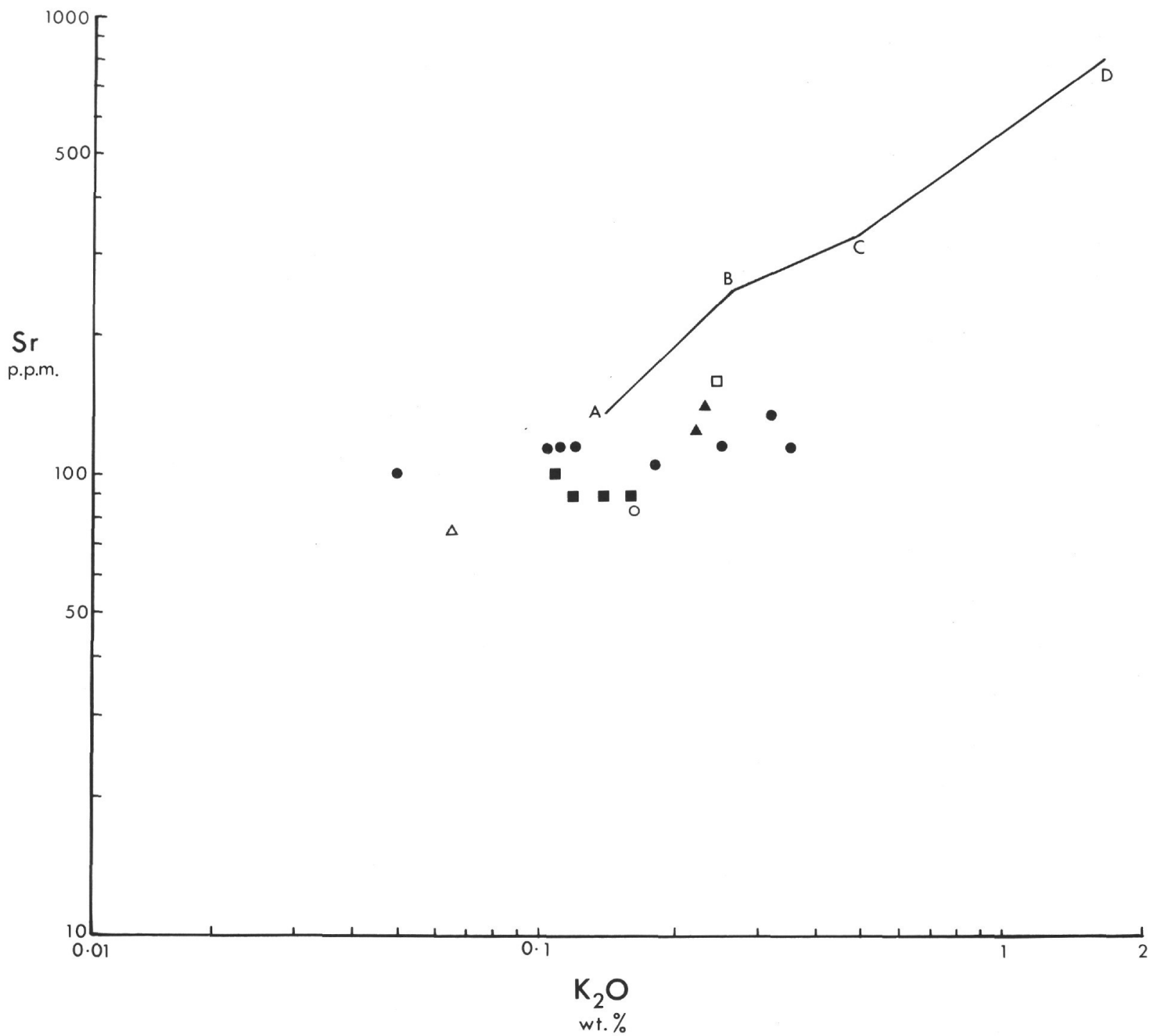

Figure 2. $\mathrm{K}_{2} \mathrm{O}$ versus $\mathrm{Sr}$ (log-log) plot for the Leg 34 basalts (after Hart et al., 1970). (A) ocean floor basalt; (B) low-K tholeiite; (C) tholeiite; (D) alkali basalt (Hart et al., 1970, Table 2). Symbols as in Figure 1 except for open triangle (average fresh Site 257 basalts) and open circle (average of all Site 257 basalts).

meters difference in depth of the contact, show totally different values from those of the remaining six, as suggested by their bulk chemistry (Table 3 ). This change is also noted by Thompson et al. (this volume), who find an increase in the lower units in the concentrations of such elements as $\mathrm{V}, \mathrm{Y}, \mathrm{Zr}, \mathrm{Sr}$, and REE, and a decrease in $\mathrm{Ni}, \mathrm{Co}$, and $\mathrm{Cr}$. The six points, however, show a practically linear trend for both $\mathrm{FeO}^{*}$ and $\mathrm{CaO}$, the only anomalous point, for $\mathrm{CaO}$, being the most altered rock (319A-5-1). Possibly this linear differentiation represents fractionation within flows (? one or more cooling units) whereas the more sudden change reflects major differentiation, in the opposite direction, within the magma chamber from which each flow derives. Until a core extending several hundred meters into layer 2 (?Leg 37) has been recovered, the true nature of fractionation upwards, discussed by Kempe (1975) cannot be determined. Figures 9 and 10 show the Site 319 curves alongside the ranges for Sites 32, 320, and 321, the cores from which are too short to be plotted against depth, and the trends for Sites 163, 146, 256, and 257. These represent all the drilled basalt sequences which can be plotted against depth for which analyses are available; as stated above, the problem will not be solved until a long core (ca $500 \mathrm{~m}$ ) is available. The Site 319 basalts show the clearest evidence of olivine phenocryst precipitation as a mechanism of fractionation, being the most convincing example of an OL-tholeiite among the long cores studied (see Figure 4). Most of the remainder, especially that from Site 257, plot as PL-tholeiites, lying in the quartz tholeiite field, in which most of the olivine phenocrysts have been destroyed by resorbtion and alteration.

The anomalous differentiation patterns in basalts from Sites 256 and 257 may perhaps be explained as part of the "rippling" or stepped curve if $\mathrm{FeO}^{*}$ or $\mathrm{CaO}$ are plotted against depth for a long core. Possibly each flow, cooling unit, or even pillow, can show its own differen- 
TABLE 5

Some Comparative Average Basalt Compositions

\begin{tabular}{|c|c|c|c|c|c|c|c|c|c|c|c|c|}
\hline & $\begin{array}{c}\text { Leg } 34 \\
\text { (Average of } \\
14 \text { Analyses) }\end{array}$ & $\begin{array}{c}\begin{array}{c}\text { Site } 319 \\
\text { (Average of } \\
8 \text { Analyses) }\end{array}\end{array}$ & $\begin{array}{l}\text { Site } 320 \\
\text { (Average of } \\
2 \text { Analyses) }\end{array}$ & $\begin{array}{c}\text { Site } 321 \\
\text { (Average of } \\
4 \text { Analyses) }\end{array}$ & $\begin{array}{c}\text { Leg } 5^{a} \\
\text { (Site 32- } \\
\text { 14-1) }\end{array}$ & $\begin{array}{c}\text { Leg } 16^{b} \\
\text { (Average of } \\
13 \text { Analyses) }\end{array}$ & $\begin{array}{l}\text { Legs } 5 \& 9^{c} \\
\text { (Average of } \\
7 \text { Analyses) }\end{array}$ & $\begin{array}{l}\text { East Pacific }{ }^{d} \\
\text { (Average of } \\
18 \text { Analyses) }\end{array}$ & $\begin{array}{c}\text { East Pacific } \\
\text { (Average of } \\
10 \text { Analyses) }\end{array}$ & $\begin{array}{l}\text { Oceanic }^{\mathbf{f}} \\
\text { tholeiite } \\
\text { (Average) }\end{array}$ & $\begin{array}{l}\text { Site } 256^{\mathrm{g}} \\
\text { (Average of } \\
3 \text { Analyses) }\end{array}$ & $\begin{array}{c}\text { Site } 257^{\mathrm{h}} \\
\text { (Average of } \\
12 \text { Analyses) }\end{array}$ \\
\hline $\mathrm{SiO}_{2}$ & 49.74 & 49.69 & 50.47 & 49.48 & 51.91 & 49.67 & 50.62 & 50.50 & 49.96 & 49.94 & 49.20 & 49.38 \\
\hline $\mathrm{TiO}_{2}$ & 1.95 & 1.78 & 1.70 & 2.41 & 3.14 & 1.66 & 1.53 & 1.80 & 1.69 & 1.51 & 2.51 & 0.91 \\
\hline $\mathrm{Al}_{2} \mathrm{O}_{3}$ & 14.25 & 14.52 & 15.47 & 13.09 & 12.58 & 14.50 & 15.75 & 15.30 & 15.52 & 17.25 & 13.18 & 15.26 \\
\hline $\mathrm{Fe}_{2} \mathrm{O}_{3}$ & 3.86 & 4.00 & 3.45 & 3.78 & - & - & - & - & 2.14 & 2.01 & 3.40 & 2.32 \\
\hline $\mathrm{FeO}$ & 7.48 & 6.82 & 5.40 & 9.83 & $15.30^{\mathrm{i}}$ & $10.30^{\mathrm{i}}$ & $9.35^{\mathrm{i}}$ & $11.00^{\mathrm{i}}$ & 8.33 & 6.90 & 9.87 & 6.08 \\
\hline $\mathrm{MnO}$ & 0.18 & 0.18 & 0.16 & 0.20 & {$[0.18]$} & {$[0.18]$} & {$[0.18]$} & {$[0.18]$} & 0.18 & 0.17 & 0.19 & 0.19 \\
\hline $\mathrm{MgO}$ & 6.73 & 6.96 & 6.79 & 6.24 & 5.04 & 7.12 & 7.67 & 7.00 & 7.25 & 7.28 & 6.10 & 8.25 \\
\hline $\mathrm{CaO}$ & 11.17 & 11.55 & 11.71 & 10.15 & 8.98 & 10.53 & 11.45 & 11.20 & 11.01 & 11.86 & 9.92 & 12.25 \\
\hline $\mathrm{Na}_{2} \mathrm{O}$ & 2.76 & 2.81 & 2.84 & 2.62 & 2.62 & 2.72 & 2.67 & 2.70 & 2.73 & 2.76 & 2.67 & 2.09 \\
\hline $\mathrm{K}_{2} \mathrm{O}$ & 0.18 & 0.19 & 0.22 & 0.13 & 0.17 & 0.32 & 0.37 & 0.18 & 0.21 & 0.16 & 0.24 & 0.16 \\
\hline $\mathrm{H}_{2} \mathrm{O}^{+}$ & 0.80 & 0.72 & 1.07 & 0.81 & - & 1.15 & - & - & 0.73 & - & 0.72 & 0.75 \\
\hline $\mathrm{H}_{2} \mathrm{O}^{-}$ & 0.82 & 0.77 & 0.92 & 0.86 & - & 0.98 & - & - & - & - & 1.28 & 1.69 \\
\hline $\mathrm{P}_{2} \mathrm{O}_{5}$ & 0.18 & 0.15 & 0.17 & 0.24 & 0.31 & {$[0.15]$} & 0.23 & {$[0.15]$} & 0.21 & 0.16 & 0.24 & 0.10 \\
\hline $\mathrm{CO}_{2}$ & 0.23 & 0.23 & 0.19 & 0.24 & - & - & - & - & - & - & 0.55 & 0.63 \\
\hline Total & 100.33 & 100.37 & 100.56 & 100.08 & 100.23 & 99.28 & 99.82 & 100.01 & 99.96 & 100.00 & 100.07 & 100.06 \\
\hline
\end{tabular}

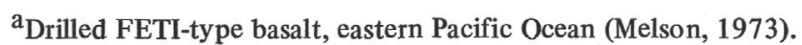

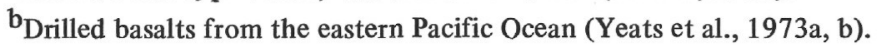

${ }^{c}$ Drilled basalts from the eastern Pacific Ocean (Melson, 1973).

${ }^{d}$ Dredged basalts from the Juan de Fuca and Gorda ridges, eastern Pacific Ocean (Kay et al., 1970).

${ }^{\mathrm{e}}$ Dredged basalts from the East Pacific Rise and the Chile Rise (Hekinian, 1971).

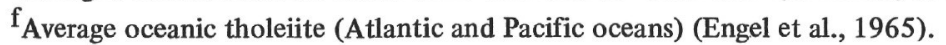

g,h Drilled FETI and "primitive" basalts from the southern Wharton Basin, Southeastern Indian Ocean (Kempe, 1974).

${ }^{\mathrm{i}}$ Total iron as $\mathrm{FeO} *$. 
TABLE 6

Normative Compositions on a $c c$-free, $\mathrm{Fe}_{2} \mathrm{O}_{3}=1.50 \%$, Basis, Recalculated to $100 \%$

\begin{tabular}{lcccr}
\hline $\begin{array}{c}\text { Sample } \\
\text { (Interval in cm) }\end{array}$ & $q$ & $d i$ & hy & ol \\
\hline 319-13-1, 77-80 & - & 71.17 & 18.21 & 10.62 \\
319A-1-1, 48-51 & - & 58.55 & 32.83 & 8.62 \\
319A-2-1, 111-114 & - & 58.32 & 30.26 & 11.42 \\
319A-3-1,78-81 & - & 56.09 & 38.30 & 5.61 \\
319A-3-5, 75-78 & - & 53.04 & 41.42 & 5.54 \\
319A-5-1, 20-22 & - & 62.25 & 16.03 & 21.72 \\
319A-6-1, 93-98 & - & 60.53 & 31.90 & 7.57 \\
319A-7-1, 121-124 & - & 55.01 & 39.31 & 5.68 \\
320B-3-1, 54-57 & - & 61.13 & 35.54 & 3.33 \\
320B-5, CC & 2.00 & 58.76 & 39.24 & - \\
321-14-1, 42-45 & 2.93 & 46.23 & 50.84 & - \\
321-14-2, 9-12 & 1.82 & 55.65 & 42.53 & - \\
$321-14-3,7-10$ & 0.79 & 45.29 & 53.92 & - \\
$321-14-4,7-10$ & 4.45 & 42.12 & 53.43 & - \\
\hline
\end{tabular}

tiation pattern, although this seems unlikely at both Sites 257 and 319, in each of which seven or more "flow units" are recognized. This concept could, of course, apply to each "flow" in a magmatic sense, rather than that in which "flows" are recognized in a drill core. In effect it would mean each effusion or burst of magma, perhaps produced by the melting of different mantle fractions and capable of producing a total thickness of lava of some 300 meters, sometimes differentiated to the maximum possible extent (Kempe, 1975). The remarkable association of "primitive" or relatively "primitive" basalt with highly fractionated rock, which occurs at Sites 256 and 257 in the Wharton Basin, and again at Sites 320 and 321 near the eastern margin of the Nazca plate, is again noted in case it relates to the differentiation patterns. Unfortunately, the Leg 34 cores are, as already stated, too short to be plotted against depth.

\section{PHASE CHEMISTRY}

Electron microprobe analyses were made of pyroxene and plagioclase feldspars from suitable sections from the three holes studied. Where possible, phenocrysts of varying type, including core and rim portions of zoned crystals, and groundmass minerals, were analyzed in

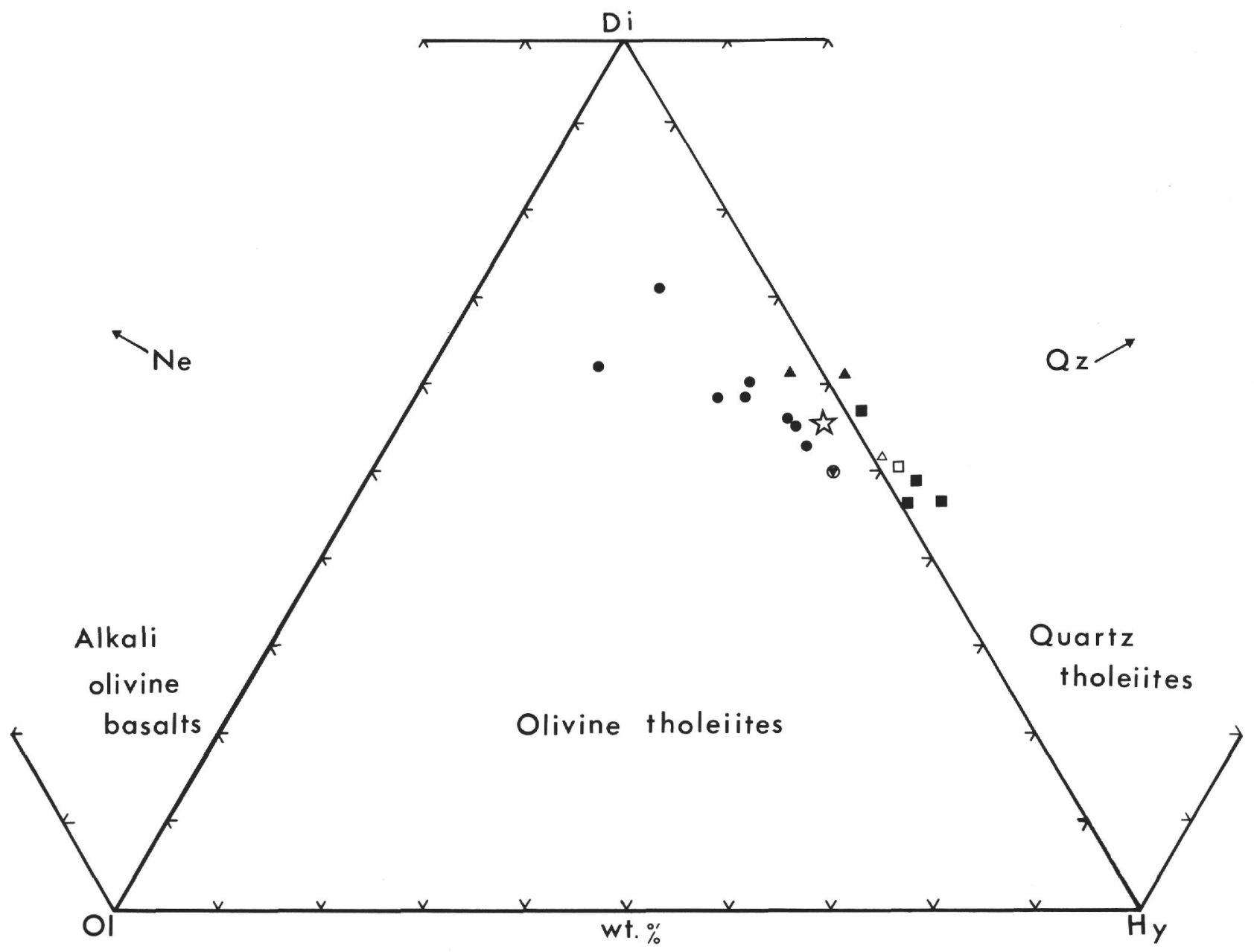

Figure 3. Normative compositions of the Leg 34 basalts, normalized on a cc-free, $\mathrm{Fe}_{2} \mathrm{O}_{3}=1.50 \%$, basis (Table 6), plotted in the Yoder and Tilley (1962) projection. Site 319 basalts are olivine tholeiites, Sites 320 and 321 are quartz tholeiites. Symbols as in Figure 1, with open star, average for Leg 34; and triangle-within-circle, average for Leg 16 basalts (Yeats et al., 1973a, b). 


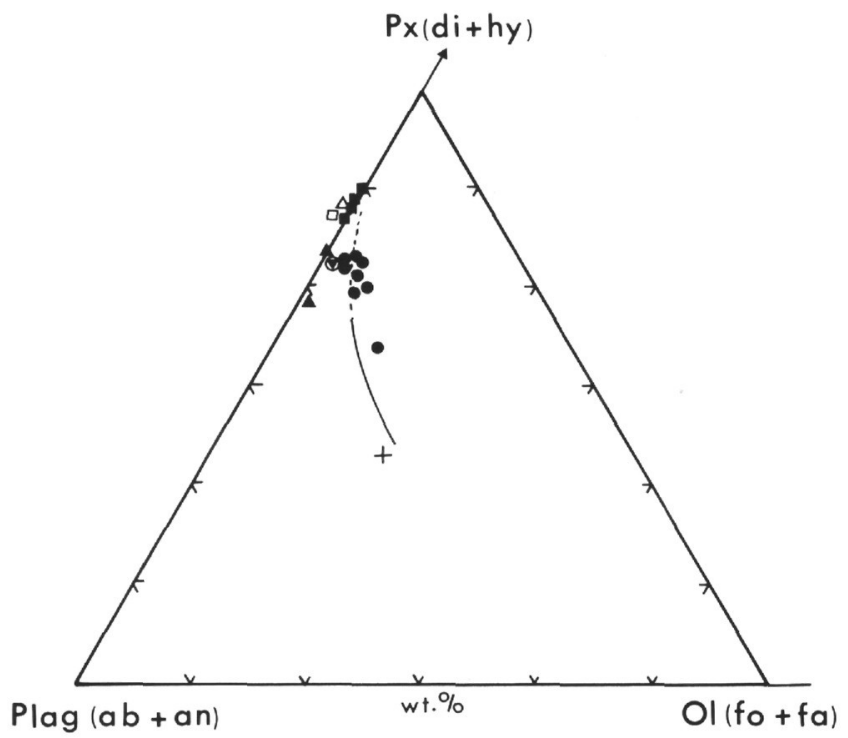

Figure 4. Leg 34 basalts plotted in the normative (normalized) diagram $P x(\mathrm{di}+\mathrm{hy})-O l(\mathrm{fo}+\mathrm{fa})-P l(\mathrm{ab}+\mathrm{an})$. The full line represents a cotectic curve (Miyashiro et al., 1970). Symbols as in Figure 1, with triangle-within-circle, average for Leg 16 basalts; cross, Site 250 basalt (Kempe, 1974).

each rock. The results are reported in Tables 7 to 14 , in which individual and average analyses are given to show typical compositions and compositional ranges. All analyses are plotted in Figures 11 and 12. Although relict olivine is present as large phenocrysts in basalts from Sample 319A-7-1, 121-124 cm and as small fresh crystals in Sample 319A-6-1, 93-98 cm, crystals suitable for analysis were not found in the probe sections. The interstitial glass and its alteration products, and ore minerals, were not studied.

The analyses were made on a Cambridge Instruments Geoscan at an accelerating voltage of $15 \mathrm{kv}$ and a specimen current of about $0.6 \times 10^{-7} \AA$. Independently analyzed minerals of appropriate composition were used as standards, except for $\mathrm{Cr}$ and $\mathrm{Mn}$ when pure metals were used. A secondary augite standard was run with all analyses as a check of precision and accuracy. Results were corrected after the method outlined by Sweatman and Long (1969), using the BM-IC-NPL computer program (Mason et al., 1969). The pyroxene analyses were checked for correct stoichiometric proportions (R.F. Symes and J.C. Bevan).

\section{Pyroxenes}

All the pyroxenes analyzed are augites (Figure 11; Tables 7 and 8); no pyroxenes of salitic or endiopsidic composition, found in some drilled basalts, were encountered.

Table 7 and Figure 11 show the relatively slight variation between the compositions of phenocryst and groundmass pyroxenes; one of the largest ranges ( $8 \%$ Fs) is between core and rim in a phenocryst from Sample $319 \mathrm{~A}-3-1,78-81 \mathrm{~cm}$. This section is perhaps the most interesting of those analyzed. Whereas the general tendency is for groundmass pyroxenes to be enriched in iron relative to magnesium when compared with phenocryst pyroxenes, owing to normal fractionation, those in 319A-3-1 have the opposite trend, although the variation is small. Core and rim variation, on the other hand, follows the expected outward iron enrichment. This rock has an unusual "runic" texture (Plate 1, Figure 3), consisting of intergrown groundmass pyroxene and plagioclase. It is possible that late and rapid quenching, possibly due to pressure changes, resulted in the intergrowth and the $\mathrm{Mg}$-rich nature of the pyroxene. Although zoned, Site 319A pyroxenes do not appear to show "compositional domains" as found in Leg 16 basalts (Yeats et al., 1973a,b). Sample 319A-5-1, 20-22 $\mathrm{cm}$ shows some exsolution of a Ca-poor pyroxene.

The augitic pyroxenes in basalts from Hole 320B and Site 321 are slightly less calcic than those from Hole 319A (Figure 11). As indicated by the bulk chemistry of the rock, Hole 320B basalt is, with the upper Hole 319 basalt, the most "primitive" of the Leg 34 rocks, with pyroxene lying close to the endiopside boundary, while augites in basalt from Site 321, as might be expected, resemble those from Site 256, Southeast Indian Ocean (Kempe, 1974).

The minor element chemistry shows that the pyroxenes contain typically small amounts of $\mathrm{MnO}$ (Yeats et al., 1973a,b) and, where determined, $\mathrm{Cr}_{2} \mathrm{O}_{3}$. Alumina is high in Site 320B basalt, and variable but high in samples from Site 319A. The Site 321 pyroxenes, as might be expected from a FETI-type rock, contain low amounts of $\mathrm{Al}_{2} \mathrm{O}_{3}$, as do those from the similar rocks from Site 256. This bulk composition characteristic is not reflected in the pyroxenes in the case of $\mathrm{TiO}_{2}$, however. Despite the high amounts of this oxide in rocks from Sites 256 and 321, the pyroxenes are notably low in $\mathrm{TiO}_{2}$, which presumably follows the (high) iron to form $\mathrm{Fe}-\mathrm{Ti}$ oxides. In pyroxenes from Sites 319 and 320, $\mathrm{TiO}_{2}$ occurs at a generally $1.5 \%$ to $2 \%$ level; it is notably low in those from 319A-3-1, where, as already mentioned, the bulk of the groundmass pyroxene is iron poor.

\section{Plagioclase Feldspars}

The plagioclase phenocrysts and groundmass laths show a fairly considerable range in composition (Figure 12, Tables 9 to 14). Basalts from Site 319A show the widest limits: Section 2-1 has $\mathrm{An}_{46-78}$, and 3-1 $\mathrm{An}_{48-82}$, with one zoned phenocryst extending to $\mathrm{An}_{42}$. The most common range is $\mathrm{An}_{60-70}$, a compositional range occupied by feldspars in typical spreading-ridge basalt such as that from Site 251, Southwest Branch of the Mid-Indian Ocean Ridge. Site 321 plagioclase is also typically An $\mathrm{A}_{60-70}$, surprisingly calcic when compared with plagioclase in the range $\mathrm{An}_{50-60}$ from the otherwise similar FETI basalt from Site 256 (Kempe, 1974).

Phenocrysts are scarce in basalts from Hole 320B and Site 321 and in those from the lower sections of Hole $319 \mathrm{~A}$. In $319 \mathrm{~A}-2-1,111-114 \mathrm{~cm}$ and $3-1,78-81 \mathrm{~cm}$, however, a variety of types are present. The order of crystallization appears to be: large, strongly zoned, equidimensional phenocrysts $\rightarrow$ small, zoned, square or stubby phenocrysts $\rightarrow$ lath-shaped phenocrysts $\rightarrow$ groundmass laths. In addition, 319A-3-1, 78-81 cm contains a 


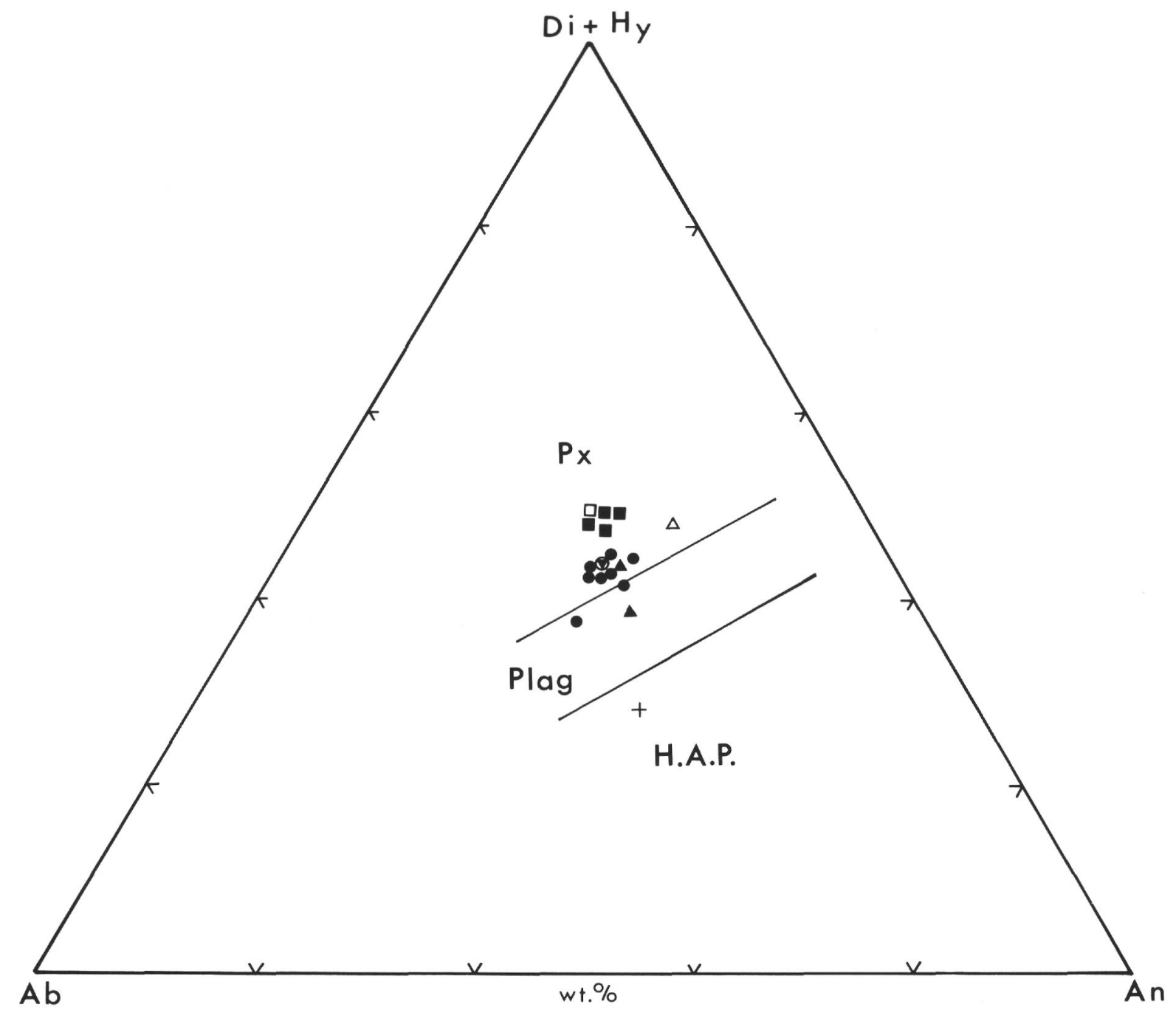

Figure 5. Leg 34 basalts plotted in the normative (normalized) pyroxene, plagioclase, and high-alumina plagioclase tholeiite diagram (di + hy) - ab - an (Hekinian and Aumento, 1973). Symbols as in Figure 4.

single large phenocryst containing a small square plagioclase "inclusion" ( $\left.\mathrm{An}_{61}\right)$, which probably represents the core. The large crystal shows reverse zoning, from inner $\mathrm{An}_{42}$ to outer rim $\mathrm{An}_{47}$; the reverse zoning is perhaps produced by pressure fluctuation (Kempe and Schilling, 1974). It is the most sodic feldspar analyzed but only slightly more so than those from $2-1,111-114 \mathrm{~cm}$.

The $\mathrm{FeO}^{*}$ and $\mathrm{MgO}$ contents were determined for some of the phenocrysts. As shown by Bryan (1972) and Bence et al. (1973), FeO* content is inversely proportional to $\mathrm{CaO}$ (Figure 13), and is ascribed to substitution for $\mathrm{Al}_{2} \mathrm{O}_{3} . \mathrm{MgO}$ is low, about $0.2 \%$, although it ranges from 0.1 to $0.3 \%$; as shown by Bence et al., it probably remains virtually constant.

\section{SUMMARY AND CONCLUSIONS}

Site 319 Bauer Deep basalt-the longest section -includes porphyritic regions and coarse ophitic rocks with embayed plagioclase. It may represent as many as eight flows or cooling units. Phenocrysts include plagioclase, some small granular pyroxenes, and large olivines not entirely altered to smectite. The pyroxene is the most calcic augite of the Leg 34 rocks, and the plagioclase lies in the total range $\mathrm{An}_{42-82}$, with at least three types of phenocryst. The olivine could not be determined. The rock is an OL-tholeiite falling in the olivine tholeiite field, but, like all the Leg 34 basalts, is a pyroxene-tholeiite in the classification of Hekinian and Aumento (1973). Again, as with all the Leg 34 basalts, the trace element characterization of Pearce and Cann (1973) shows the rock to be typical OFB. The overall chemistry is typical of LIL-element-depleted MORB; and the basalt is fairly highly fractionated with respect to $\mathrm{FeO}^{*} / \mathrm{MgO}$. Evidence of differentiation is clearly present within the lower part of the 60-meter sequence, showing enrichment upwards in iron and alkalis relative to magnesium and calcium. The upper part, based on two samples, shows a strong trend in the opposite (more "primitive") direction.

Site 320 basalt is variolitic and barely porphyritic, and is thought to occur as thin flows or pillows forming at least 10 cooling units. It is a relatively "primitive" PLtholeiite, with an average composition falling in the 


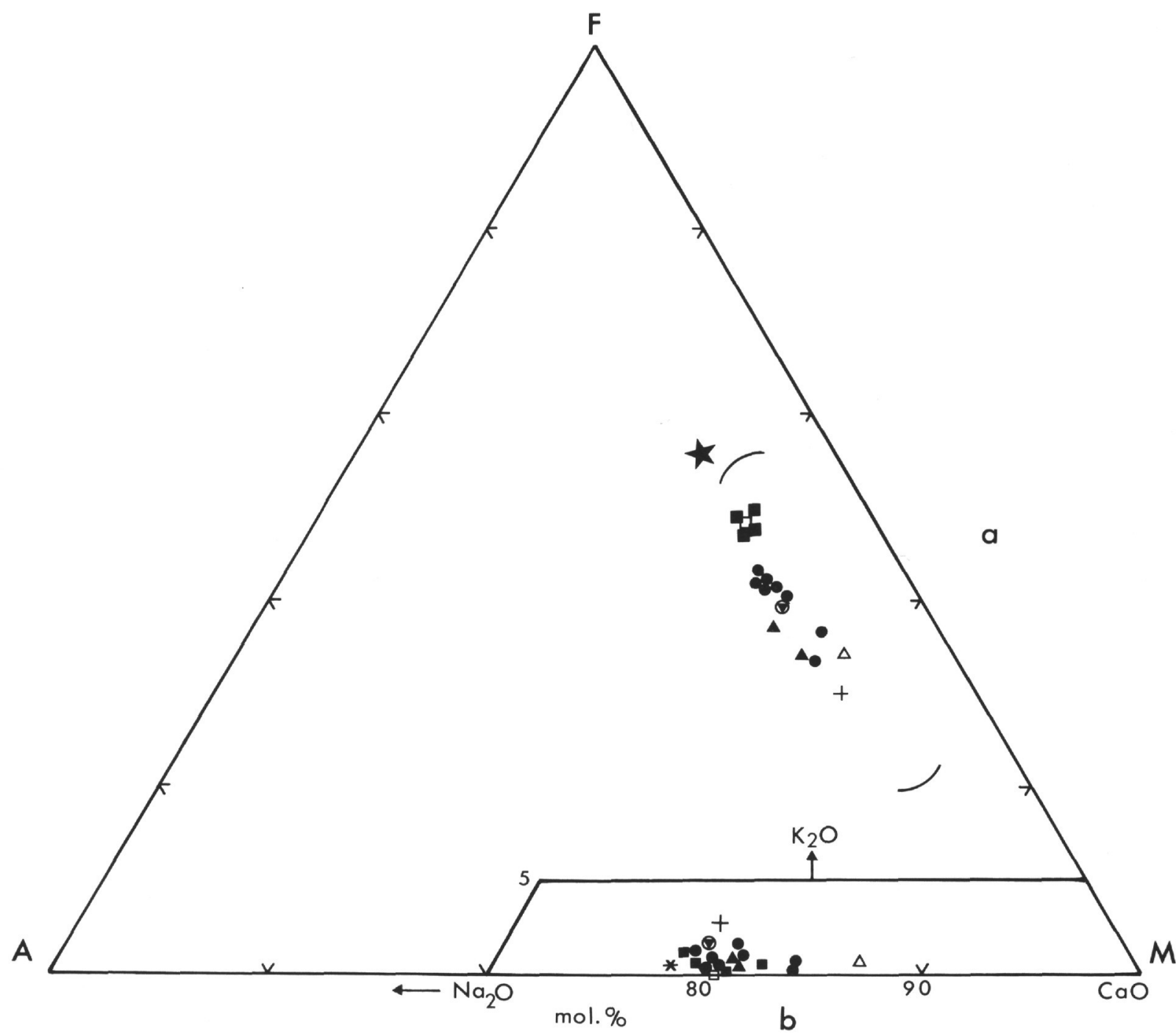

Figure 6. (a) FMA diagram of the Leg 34 basalts. Brackets enclose area filled by Mid-Atlantic Ridge rocks, including the iron-rich gabbros, of Miyashiro et al. (1970). Symbols as in Figure 5, with solid star, FETI basalt from Site 32 (Melson, 1973). (b) Lime-alkalis diagram of the Leg 34 basalts. Symbols as in Figure 6a.

quartz tholeiite field, and containing augite and plagioclase near $\mathrm{An}_{70}$.

Site 321 basalt is also from the eastern margin of the Nazca plate. It has a variable texture, with rare phenocrysts, and is fairly vesicular, unlike the first two basalt types. It is thought to represent two extrusive units, although most falls within one unit. Olivine was not noted in the samples studied; the pyroxene is an Al- and Tipoor augite and the plagioclase $\mathrm{An}_{60-70}$. Again it is a PLtholeiite, fairly pyroxene-rich, and the most quartznormative of the Leg 34 rocks. It is highly fractionated and thus of considerable interest. Because of the short cores recovered, differentiation could not be plotted against depth.

However, the Site 320 and 321 basalts are remarkable in that two contrasted types, one relatively "primitive" and one highly fractionated, are found fairly close together, although separated by a fracture zone. A similar situation occurs in the "ancient" crust of the southern Wharton Basin, Southeastern Indian Ocean, where very "primitive" or primary (?high pressure) basalt (Site 257) occurs fairly close to highly fractionated (?low pressure) FETI-type basalt at Site 256, both showing anomalous differentiation patterns.

\section{ACKNOWLEDGMENTS}

Dr. A.C. Bishop is sincerely thanked for reviewing the manuscript and making many helpful suggestions. J.V. Brown took the photomicrographs.

\section{REFERENCES}

Aumento, F. and Loncarevic, B.D., 1969. The Mid-Atlantic Ridge near $45^{\circ}$ N. IV. Bald Mountain: Canadian J. Earth Sci., v. 6, p. 11.

Bass, M.N., Moberly, R.M., Rhodes, J.M., Shih, C-y., and Church, S.E., 1973. Volcanic rocks cored in the central Pacific, Leg 17, Deep Sea Drilling Project. In Winterer, E.L., Ewing, J.I., et al., Initial Reports of the Deep Sea Drilling Project, Volume 17: Washington (U.S. Government Printing Office), p. 429. 


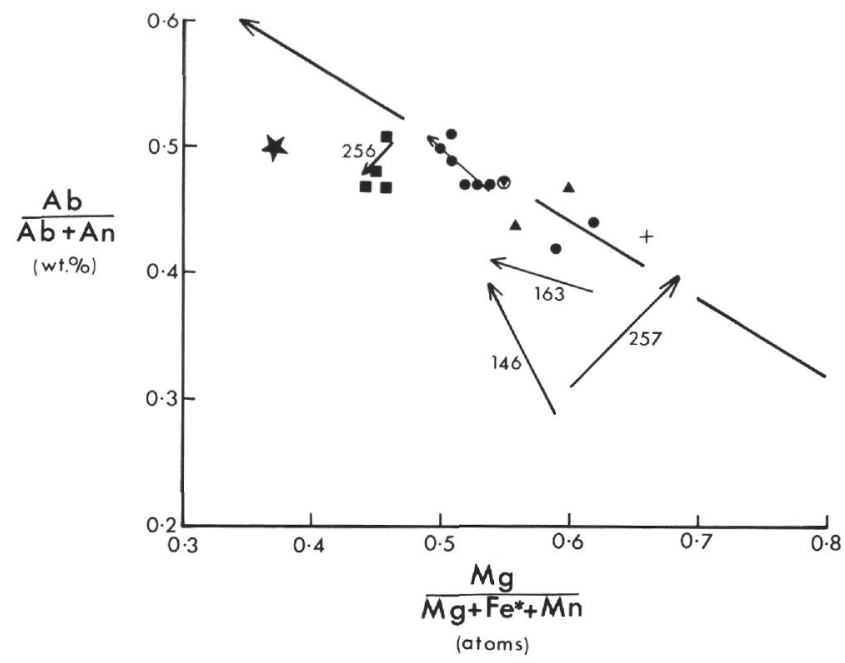

Figure 7. Fractionation diagram ( $A b /[A b+A n]$ vs $M g /[M g$ $+F e^{*+M n]) ~ f o r ~ t h e ~ L e g ~} 34$ basalts. Also shown are basalt fractionation trends for Site 163 (Yeats et al., 1973 $a$, b) and Sites 256 and 257 (Kempe, 1974); the dolerite trend for Site 146 (Donnelly et al., 1973); and the point (solid star) for Site 32 (Melson, 1973). The long broken arrow indicates the generalized fractionation trend for tholeiitic rocks. Symbols as in Figure 6.

Bence, A.E., Papike, J.J., Chandrasekharam, D., Cameron, M., and Camenisch, S., 1973. Petrology of basalts from Leg 15 of the Deep Sea Drilling Project: the central Caribbean: EOS, v. 54, p. 995 (abstract).

Bryan, W.B., 1972. Mineralogical studies of submarine basalts: Yearbook Carnegie Institution Washington, 71, p. 396.

Christensen, N.I., Frey, F.A., MacDougall, D., Melson, W.G., Peterson, M.N.A., Thompson, G., and Watkins, N.D., 1973. Deep Sea Drilling Project: properties of igneous and metamorphic rocks of the oceanic crust: EOS, v. 54, p. 972.

Donnelly, T.W., Melson, W.G., Kay, R., and Rogers, J.J.W., 1973. Basalts and dolerites of Late Cretaceous age from the central Caribbean. In Edgar, N.T., Saunders, J.B., et al., Initial Reports of the Deep Sea Drilling Project, Volume 15: Washington (U.S. Government Printing Office), p. 989.

Engel, A.E.J., Engel, C.G., and Havens, R.G., 1965. Chemical characteristics of oceanic basalts and the upper mantle: Geol. Soc. Am. Bull., v. 76, p. 719.

French, W.J. and Adams, S.J., 1972. A rapid method for the extraction and determination of iron (II) in silicate rocks and minerals: Analyst (London), v. 97, p. 828.

Frey, F.A., Bryan, W.B., and Thompson, G., 1974. Atlantic ocean floor: Geochemistry and petrology of basalts from Legs 2 and 3 of the Deep Sea Drilling Project: J. Geophys. Res., vol. 79, p. 5507.

Hart, S.R., Brooks, C., Krogh, T.E., Davis, G.L., and Nava, D., 1970. Ancient and modern volcanic rocks: a trace element model: Earth Planet. Sci. Lett., v. 10, p. 17.

Hekinian, R., 1971. Chemical and mineralogical differences between abyssal hill basalts and ridge tholeiites in the eastern Pacific Ocean: Marine Geol., v. 11, p. 77.

Hekinian, R. and Aumento, F., 1973. Rocks from the Gibbs fracture zone and the Minia seamount near $53^{\circ} \mathrm{N}$ in the Atlantic Ocean: Marine Geol., v. 14, p. 47.

Hyndman, R.D., 1974. Seismic velocities of basalts from DSDP Leg 26. In Davies, T.A., Luyendyk, B.P., et al.,

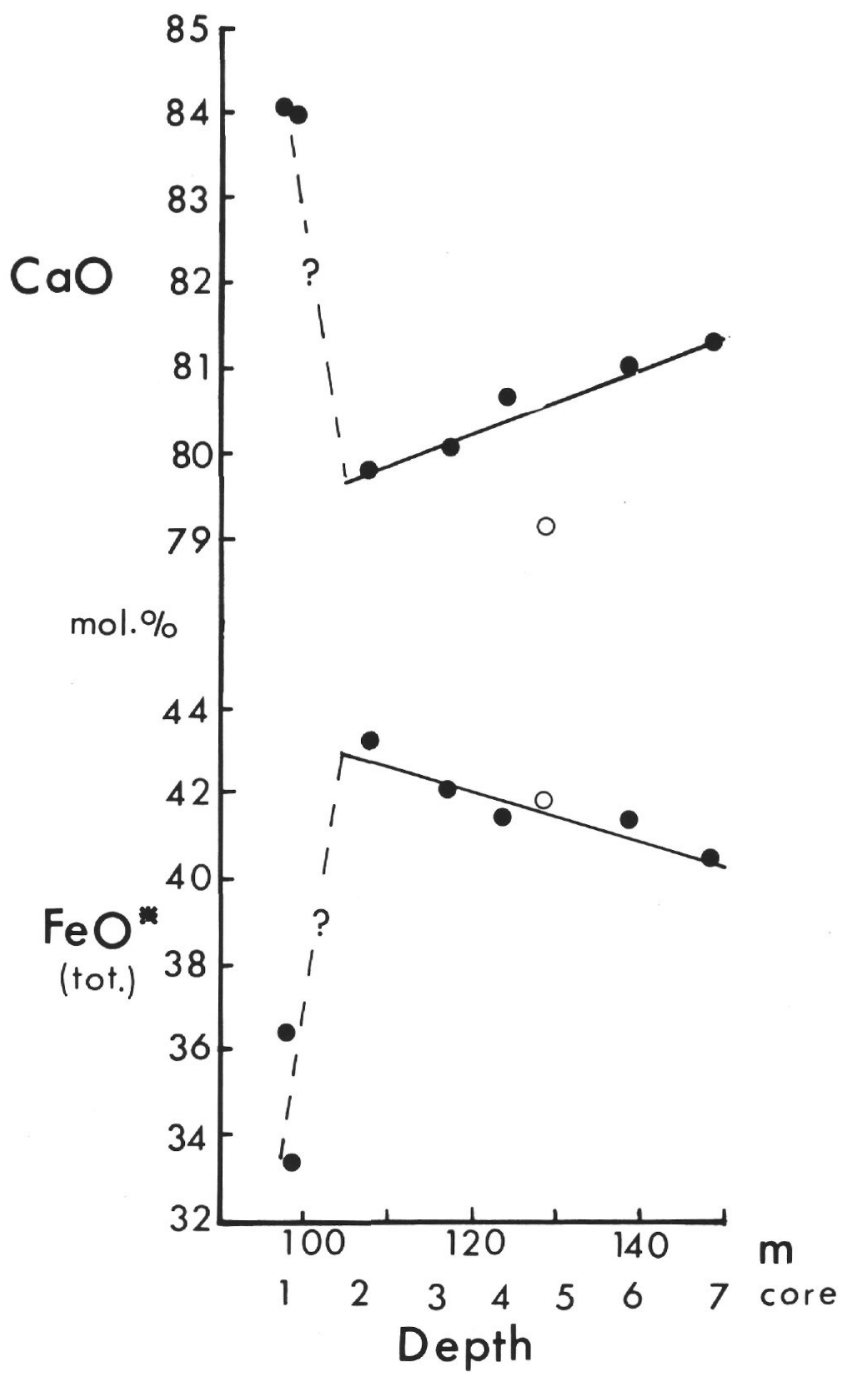

Figure 8. $\mathrm{FeO}$ * from the $\mathrm{FMA}$ diagram, and $\mathrm{CaO}$ from the lime-alkalis diagram, for Site 319 basalts plotted against depth below the sediment-basalt contact. Open circle, altered material. The linear differentiation may represent fractionation within flows while the more sudden change reflects major differentiation within the magma chamber from which each flow derives.

Initial Reports of the Deep Sea Drilling Project, Volume 26: Washington (U.S. Government Printing Office), p. 509.

Kay, R., Hubbard, N.J., and Gast, P.W., 1970. Chemical characteristics and origin of oceanic ridge volcanic rocks: J. Geophys. Res., v. 75, p. 1585.

Kempe, D.R.C., 1974. The petrology of the basalts, DSDP Leg 26. In Davies T.A., Luyendyk, B.P., et al., Initial Reports of the Deep Sea Drilling Project, Volume 26: Washington (U.S. Government Printing Office), p. 465. 1975. Normative mineralogy and differentiation patterns of some drilled and dredged oceanic basalts: Contrib. Min. Petrol., v. 50, p. 305.

Kempe, D.R.C. and Schilling, J-G., 1974. Discovery tablemount basalt: petrology and geochemistry: Contrib. Min. Petrol., v. 44, p. 101.

Kuno, H., 1960. High-alumina basalt: J. Petrol., v. 1, p. 121.

Langmyhr, R.J. and Paus, P.E., 1968. The analysis of inorganic siliceous materials by atomic absorption spec- 


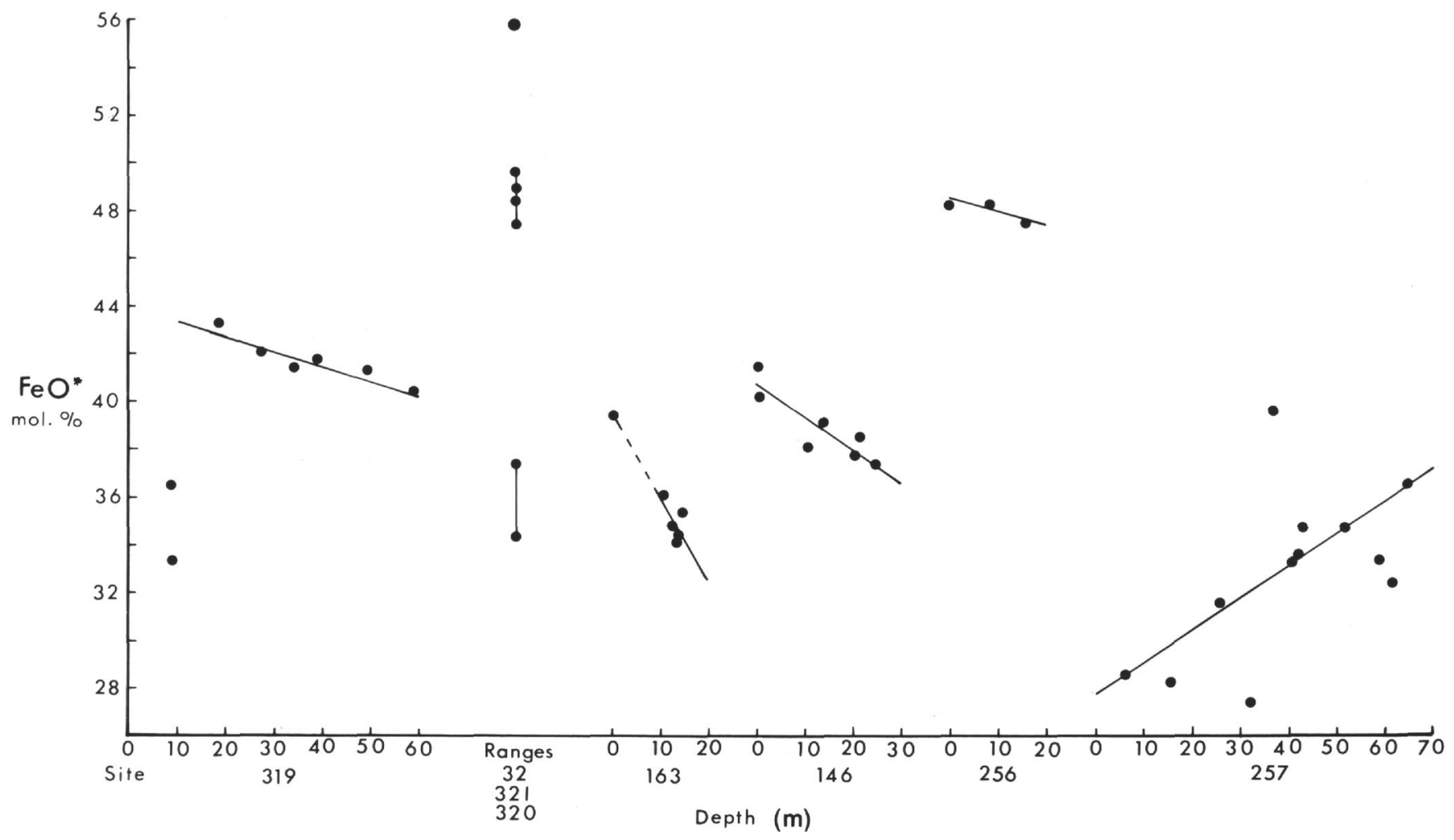

Figure 9. $\mathrm{FeO}$ * from the FMA diagrams plotted against depth below the sediment-basalt contact for all DSDP basalt cores of sufficient length, to show varying fractionation trends. Other values are shown as points or ranges (Sites 32, 320, and 321). Sources of data as in Figure 7.

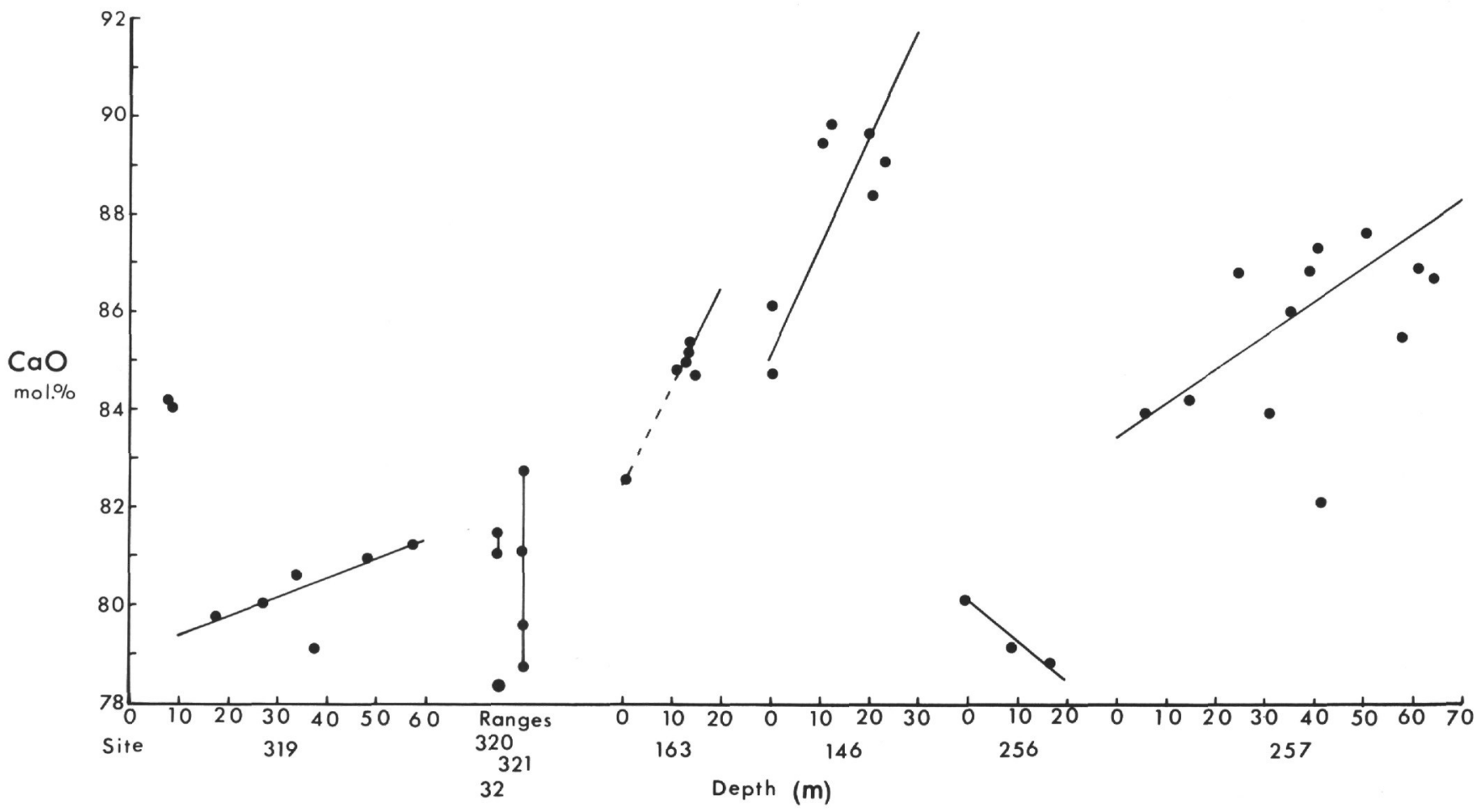

Figure 10. CaO from the lime-alkali diagrams plotted against depth below the sediment-basalt contact for all DSDP basalt cores of sufficient length to show varying fractionation trends. Other values are shown as points or ranges (Sites 32, 320, and 321). Sources of data as in Figure 7. 
TABLE 7

Pyroxene Analyses, Site 319A ${ }^{a}$

\begin{tabular}{|c|c|c|c|c|c|c|c|c|c|c|c|}
\hline & \multicolumn{3}{|c|}{$2-1,111-114 \mathrm{~cm}$} & \multicolumn{5}{|c|}{$3-1,78-81 \mathrm{~cm}$} & \multirow{2}{*}{$\begin{array}{c}5-1,20-22 \mathrm{~cm} \\
\text { Groundmass } \\
\text { (av. of } 4)\end{array}$} & \multicolumn{2}{|c|}{$7-1,121-124 \mathrm{~cm}$} \\
\hline & $\begin{array}{l}\text { Phenocryst } \\
\text { (av. of 2) }\end{array}$ & $\begin{array}{l}\text { Plumose } \\
\text { "Crystals" } \\
\text { (av. of 2) }\end{array}$ & $\begin{array}{c}\text { Mosaic } \\
\text { Groundmass }\end{array}$ & $\begin{array}{l}\text { Phenc } \\
\text { Core }\end{array}$ & $\begin{array}{l}\text { cryst } \\
\text { Rim }\end{array}$ & $\begin{array}{l}\text { Phenocryst } \\
\text { (Core) }\end{array}$ & $\begin{array}{l}\text { Phenocryst } \\
\text { (Near Core) }\end{array}$ & $\begin{array}{l}\text { Groundmass } \\
\text { (av. of 3) }\end{array}$ & & Groundmass & $\begin{array}{l}\text { Groundmass } \\
\text { (av. of 2) }\end{array}$ \\
\hline $\mathrm{SiO}_{2}$ & 49.22 & 49.18 & 49.39 & 50.93 & 50.44 & 51.06 & 50.48 & 50.68 & 49.92 & 49.13 & 49.61 \\
\hline $\mathrm{TiO}_{2}$ & 1.55 & 1.68 & 1.75 & 1.12 & 1.24 & 1.12 & 1.26 & 1.39 & 1.59 & 1.65 & 1.83 \\
\hline $\mathrm{Al}_{2} \mathrm{O}_{3}$ & 5.20 & 4.32 & 5.77 & 3.45 & 2.24 & 2.98 & 2.55 & 3.72 & 4.11 & 4.40 & 3.86 \\
\hline $\mathrm{Cr}_{2} \mathrm{O}_{3}$ & n.d. ${ }^{b}$ & n.d. ${ }^{b}$ & n.d. ${ }^{b}$ & 0.26 & nil & 0.12 & nil & 0.19 & 0.13 & n.d. ${ }^{b}$ & n.d. ${ }^{b}$ \\
\hline $\mathrm{FeO}^{*}$ & 9.89 & 11.01 & 8.11 & 8.27 & 13.23 & 10.16 & 13.08 & 8.67 & 8.66 & 10.80 & 12.35 \\
\hline $\mathrm{MnO}$ & 0.20 & 0.24 & 0.13 & 0.24 & 0.36 & 0.28 & 0.33 & 0.23 & 0.23 & n.d. ${ }^{b}$ & n.d. ${ }^{b}$ \\
\hline $\mathrm{MgO}$ & 14.04 & 13.99 & 14.53 & 15.66 & 14.13 & 15.39 & 14.28 & 15.85 & 15.30 & 13.94 & 13.50 \\
\hline $\mathrm{CaO}$ & 19.53 & 19.80 & 20.41 & 20.00 & 18.13 & 19.06 & 18.47 & 19.49 & 19.64 & 19.58 & 18.68 \\
\hline $\mathrm{Na}_{2} \mathrm{O}$ & 0.32 & 0.34 & 0.28 & 0.32 & 0.32 & 0.31 & 0.30 & 0.30 & 0.35 & 0.35 & 0.35 \\
\hline $\mathrm{K}_{2} \mathrm{O}$ & n.d. ${ }^{b}$ & n.d. ${ }^{b}$ & n.d. ${ }^{b}$ & n.d. ${ }^{b}$ & n.d. ${ }^{b}$ & n.d. ${ }^{b}$ & n.d. ${ }^{b}$ & n.d. ${ }^{b}$ & 0.02 & n.d. ${ }^{b}$ & n.d. ${ }^{b}$ \\
\hline Total & 99.95 & 100.56 & 100.37 & 100.25 & 100.09 & 100.48 & 100.75 & 100.52 & 99.95 & 99.85 & 100.18 \\
\hline $\mathrm{Mg}$ & 42.0 & 40.7 & 43.1 & 45.2 & 40.9 & 44.2 & 40.9 & 45.7 & 44.5 & 40.9 & 39.9 \\
\hline $\mathrm{Fe}$ & 16.2 & 18.0 & 13.5 & 13.4 & 21.5 & 16.4 & 21.0 & 14.0 & 14.3 & 17.8 & 20.5 \\
\hline $\mathrm{Ca}$ & 41.8 & 41.3 & 43.4 & 41.4 & 37.6 & 39.4 & 38.1 & 40.3 & 41.2 & 41.3 & 39.6 \\
\hline
\end{tabular}

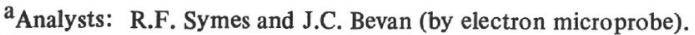

$b_{\text {n.d. }}=$ not determined.

TABLE 8

Pyroxene Analyses, Hole $320 \mathrm{~B}$ and Site $321^{\mathrm{a}}$

\begin{tabular}{|c|c|c|c|c|c|}
\hline & $\begin{array}{c}\text { 320B-3-1, } \\
54-57 \\
\text { Groundmass } \\
\text { (av. of 2) }\end{array}$ & $\begin{array}{c}\text { 320B-3-1, } \\
54-57 \\
\text { Groundmass }\end{array}$ & $\begin{array}{c}\text { 321-14-4, } \\
7-10 \\
\text { Groundmass } \\
\text { (av. of 2) }\end{array}$ & $\begin{array}{c}\text { 321-14-4, } \\
7-10 \\
\text { Groundmass } \\
\text { (av. of 2) }\end{array}$ & $\begin{array}{c}\text { 321-14-4, } \\
7-10 \\
\text { Groundmass }\end{array}$ \\
\hline $\mathrm{SiO}_{2}$ & 49.51 & 50.88 & 51.32 & 51.52 & 50.63 \\
\hline $\mathrm{TiO}_{2}$ & 1.57 & 1.94 & 0.93 & 1.05 & 1.13 \\
\hline $\mathrm{Al}_{2} \mathrm{O}_{3}$ & 5.07 & 5.73 & 2.46 & 2.81 & 2.65 \\
\hline $\mathrm{Cr}_{2} \mathrm{O}_{3}$ & n.d. ${ }^{b}$ & n.d. ${ }^{b}$ & n.d. ${ }^{b}$ & n.d. ${ }^{b}$ & n.d. ${ }^{b}$ \\
\hline $\mathrm{FeO}^{*}$ & 7.95 & 10.95 & 9.69 & 11.24 & 12.32 \\
\hline $\mathrm{MnO}$ & n.d. ${ }^{b}$ & n.d. ${ }^{b}$ & 0.08 & n.d. ${ }^{b}$ & 0.25 \\
\hline $\mathrm{MgO}$ & 16.30 & 15.72 & 16.71 & 16.00 & 15.40 \\
\hline $\mathrm{CaO}$ & 18.90 & 14.46 & 17.93 & 18.34 & 17.56 \\
\hline $\mathrm{Na}_{2} \mathrm{O}$ & 0.25 & 0.33 & 0.13 & 0.09 & 0.20 \\
\hline $\mathrm{K}_{2} \mathrm{O}$ & n.d. ${ }^{b}$ & n.d. ${ }^{b}$ & 0.02 & 0.03 & 0.06 \\
\hline Total & 99.55 & 100.01 & 99.27 & 101.08 & 100.20 \\
\hline $\mathrm{Mg}$ & 47.4 & 48.7 & 47.7 & 45.1 & 44.1 \\
\hline $\mathrm{Fe}$ & 13.1 & 19.1 & 15.5 & 17.8 & 19.8 \\
\hline $\mathrm{Ca}$ & 39.5 & 32.2 & 36.8 & 37.1 & 36.1 \\
\hline
\end{tabular}

analysts: R.F. Symes and J.C. Bevan (by electron microprobe).

$\mathrm{b}_{\text {n.d. }}=$ not determined.

trophotometry and the hydrofluoric acid decomposition technique. Part I: the analysis of silicate rocks: Anal. Chim. Acta, v. 43, p. 397.

Mason, P.K., Frost, M.T., and Reed, S.J.B., 1969. B.M.-I.C.N.P.L. computer program for calculating corrections in quantitative X-ray microanalysis: Nat. Phys. Lab. (U.K.) Rept. 1.

Melson, W.G., 1973. Basaltic glasses from the Deep Sea Drilling Project: chemical characteristics, compositions of alteration products, and fission track 'ages': EOS, v. 54, p. 1011 (abstract).
Norrish, K. and Hutton, J.T., 1969. An accurate X-ray spectrographic method for the analysis of a wide range of geological samples: Geochim. Cosmochim. Acta, v. 33, p. 431.

Pearce, J.A. and Cann, J.R., 1973. Tectonic setting of basic volcanic rocks determined using trace element analyses: Earth Planet. Sci. Lett., v. 19, p. 290.

Shido, F., Miyashiro, A., and Ewing, M., 1971. Crystallization of abyssal tholeiites: Contrib. Min. Petrol.. v. 31, p. 251.

Sweatman, T.R. and Long, J.V.P., 1969. Quantitative electron-probe microanalysis of rock-forming minerals: $J$. Petrol., v. 10, p. 332. 
TABLE 9

Plagioclase Feldspar Analyses, Sample 319A-2-1, 111-114 $\mathrm{cm}^{\mathrm{a}}$

\begin{tabular}{|c|c|c|c|c|c|c|c|}
\hline & \multirow{2}{*}{\multicolumn{2}{|c|}{$\begin{array}{c}\text { Zoned Square } \\
\text { Phenocryst }\end{array}$}} & \multirow{3}{*}{$\begin{array}{c}\text { Large } \\
\text { Square } \\
\text { Phenocryst }\end{array}$} & \multirow{3}{*}{$\begin{array}{l}\text { Untwinned } \\
\text { Irregular } \\
\text { Phenocryst }\end{array}$} & \multicolumn{2}{|c|}{$\begin{array}{l}\text { Lath-Type } \\
\text { Phenocryst }\end{array}$} & \multirow{3}{*}{$\begin{array}{l}\text { Groundmass } \\
\text { (av. of } 3 \text { ) }\end{array}$} \\
\hline & & & & & \multirow{2}{*}{$\begin{array}{c}\text { Core } \\
\text { (av. of 2) }\end{array}$} & \multirow[b]{2}{*}{ Rim } & \\
\hline & Core & Rim & & & & & \\
\hline $\mathrm{SiO}_{2}$ & 48.08 & 52.91 & 50.12 & 52.43 & 51.04 & 55.51 & 56.59 \\
\hline $\mathrm{Al}_{2} \mathrm{O}_{3}$ & 32.24 & 28.26 & 31.17 & 29.14 & 29.08 & 26.64 & 26.84 \\
\hline $\mathrm{FeO}^{*}$ & 0.47 & n.d. ${ }^{b}$ & 0.52 & 0.72 & 0.74 & n.d. ${ }^{b}$ & n.d. ${ }^{b}$ \\
\hline $\mathrm{MgO}$ & n.d. b & n.d. ${ }^{b}$ & n.d. ${ }^{b}$ & n.d. ${ }^{b}$ & n.d. ${ }^{b}$ & n.d. ${ }^{b}$ & n.d. ${ }^{b}$ \\
\hline $\mathrm{CaO}$ & 16.24 & 12.63 & 14.76 & 13.08 & 13.79 & 9.92 & 9.83 \\
\hline $\mathrm{Na}_{2} \mathrm{O}$ & 2.44 & 4.55 & 3.17 & 4.25 & 4.03 & 6.28 & 5.88 \\
\hline $\mathrm{K}_{2} \mathrm{O}$ & 0.04 & 0.05 & 0.04 & 0.05 & 0.06 & 0.09 & 0.08 \\
\hline Total & 99.51 & 98.40 & 99.78 & 99.67 & 98.74 & 98.44 & 99.22 \\
\hline $\mathrm{Ab}$ & 21.3 & 39.3 & 27.9 & 36.9 & 34.5 & 53.1 & 51.7 \\
\hline An & 78.5 & 60.4 & 71.8 & 62.8 & 65.2 & 46.4 & 47.8 \\
\hline Or & 0.2 & 0.3 & 0.2 & 0.3 & 0.3 & 0.5 & 0.5 \\
\hline
\end{tabular}

${ }^{a}$ Analysts: R.F. Symes and J.C. Bevan (by electron microprobe).

$b_{\text {n.d. }}=$ not determined.

TABLE 10

Plagioclase Feldspar Analyses, Sample 319A-3-1, 78-81 cma

\begin{tabular}{|c|c|c|c|c|c|c|c|c|c|c|c|c|c|}
\hline & \multicolumn{2}{|c|}{ Phenocryst } & \multicolumn{2}{|c|}{$\begin{array}{l}\text { Lath-Type } \\
\text { Phenocryst }\end{array}$} & \multicolumn{2}{|c|}{$\begin{array}{l}\text { Lath-Type } \\
\text { Phenocryst }\end{array}$} & \multicolumn{2}{|c|}{$\begin{array}{l}\text { Small Square } \\
\text { Phenocryst }\end{array}$} & \multicolumn{3}{|c|}{$\begin{array}{l}\text { Large Phenocryst } \\
\text { With Square Inclusion }\end{array}$} & \multirow[b]{2}{*}{$\begin{array}{l}\text { Groundmass } \\
\text { (av. of 2) }\end{array}$} & \multirow[b]{2}{*}{ Groundmass } \\
\hline & Core & Rim & Core & Rim & $\begin{array}{c}\text { Core } \\
\text { (av. of 2) }\end{array}$ & Rim & Core & Rim & Core & Rim & Inclusion & & \\
\hline $\mathrm{SiO}_{2}$ & 48.26 & 54.49 & 48.63 & 52.90 & 52.92 & 56.81 & 53.61 & 54.37 & 58.84 & 57.92 & 53.99 & 53.29 & 54.02 \\
\hline $\mathrm{Al}_{2} \mathrm{O}_{3}$ & 32.76 & 28.26 & 31.99 & 29.98 & 29.40 & 26.77 & 29.09 & 28.46 & 25.29 & 26.19 & 28.18 & 29.17 & 27.79 \\
\hline $\mathrm{FeO}^{*}$ & 0.40 & n.d. ${ }^{b}$ & 0.52 & n.d. ${ }^{b}$ & 0.71 & n.d. ${ }^{b}$ & 0.71 & n.d. ${ }^{b}$ & 0.78 & n.d. ${ }^{b}$ & n.d. ${ }^{b}$ & n.d. ${ }^{b}$ & n.d. ${ }^{b}$ \\
\hline $\mathrm{MgO}$ & 0.20 & n.d. ${ }^{b}$ & 0.17 & n.d. ${ }^{b}$ & 0.23 & n.d. ${ }^{b}$ & 0.24 & n.d. ${ }^{b}$ & 0.11 & n.d. ${ }^{b}$ & n.d. ${ }^{b}$ & n.d. ${ }^{b}$ & n.d. ${ }^{b}$ \\
\hline $\mathrm{CaO}$ & 17.12 & 11.89 & 16.61 & 13.41 & 13.32 & 9.86 & 12.90 & 12.32 & 8.79 & 9.53 & 12.70 & 12.66 & 11.83 \\
\hline $\mathrm{Na}_{2} \mathrm{O}$ & 2.10 & 4.74 & 2.21 & 3.86 & 4.18 & 5.80 & 4.30 & 4.89 & 6.72 & 5.97 & 4.49 & 4.20 & 5.15 \\
\hline $\mathrm{K}_{2} \mathrm{O}$ & 0.03 & 0.06 & 0.03 & 0.06 & 0.06 & 0.08 & 0.05 & 0.06 & 0.11 & 0.10 & 0.05 & 0.05 & 0.06 \\
\hline Total & 100.87 & 99.44 & 100.16 & 100.21 & 100.82 & 99.32 & 100.90 & 100.10 & 100.64 & 99.71 & 99.41 & 99.37 & 98.85 \\
\hline $\mathbf{A b}$ & 18.0 & 41.8 & 19.2 & 34.2 & 36.0 & 51.3 & 37.6 & 41.7 & 57.3 & 52.5 & 38.7 & 37.3 & 43.8 \\
\hline An & 81.8 & 57.7 & 80.6 & 65.3 & 63.5 & 48.2 & 61.9 & 57.8 & 41.9 & 46.7 & 60.8 & 62.2 & 55.8 \\
\hline Or & 0.2 & 0.5 & 0.2 & 0.5 & 0.5 & 0.5 & 0.5 & 0.5 & 0.8 & 0.8 & 0.5 & 0.5 & 0.4 \\
\hline
\end{tabular}

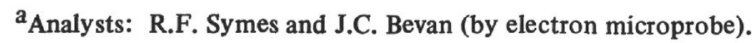

$\mathrm{b}_{\text {n.d. }}=$ not determined.

Yeats, R.S., Forbes, W.C., Heath, G.R., and Scheidegger, K.F., 1973a. Petrology and geochemistry of DSDP Leg 16 basalts, eastern equatorial Pacific. In van Andel, T.H., Heath. G.R.. et al., Initial Reports of the Deep Sea Drilling Project, Volume 16: Washıngton (U.S. Government Printing Office), p. 617.

Miyashiro, A., Shido, F., and Ewing, M., 1969. Diversity and origin of abyssal tholeiite from the Mid-Atlantic Ridge near $24^{\circ}$ and $30^{\circ}$ North latitude: Contrib. Min. Petrol., v. 23 , p. 38 .
1970. Crystallization and differentiation in abyssal tholeiites and gabbros from mid-oceanic ridges: Earth Planet. Sci. Lett., v. 7, p. 361 .

Yeats, R.S., Forbes, W.C., Scheidegger, K.F., Heath, G.R., and van Andel, Tj.H., 1973b. Core from Cretaceous basalt, central equatorial Pacific, Leg 16, Deep Sea Drilling Project: Geol. Soc. Am. Bull., v. 84, p. 871.

Yoder, H.S., Jr., and Tilley, C.E., 1962. Origin of basalt magmas: an experimental study of natural and synthetic rock systems: J. Petrol., v. 3, p. 342. 
TABLE 11

Plagioclase Feldspar Analyses, Sample 319A-5-1, 20-22 $\mathrm{cm}^{\mathrm{a}}$

\begin{tabular}{lccccc}
\hline & $\begin{array}{c}\text { Zoned } \\
\text { Euhedral } \\
\text { Phenocryst } \\
\text { (Core) }\end{array}$ & $\begin{array}{c}\text { Lath-Type } \\
\text { Phenocryst } \\
\text { (Core) }\end{array}$ & $\begin{array}{c}\text { Lath-Type } \\
\text { Phenocryst }\end{array}$ & $\begin{array}{c}\text { Stubby } \\
\text { Phenocryst }\end{array}$ & $\begin{array}{c}\text { Groundmass } \\
\text { (av. of 2) }\end{array}$ \\
\hline $\mathrm{SiO}_{2}$ & 48.12 & 48.57 & 49.24 & 52.43 & 52.88 \\
$\mathrm{Al}_{2} \mathrm{O}_{3}$ & 31.33 & 31.49 & 30.64 & 27.93 & 28.52 \\
$\mathrm{FeO}^{*}$ & 0.48 & 0.41 & 0.50 & 0.72 & n.d. \\
$\mathrm{MgO}$ & 0.20 & 0.24 & 0.21 & 0.27 & n.d. \\
$\mathrm{CaO}$ & 17.00 & 16.58 & 16.06 & 13.65 & 13.01 \\
$\mathrm{Na} 2 \mathrm{O}$ & 2.16 & 2.41 & 2.54 & 3.62 & 4.09 \\
$\mathrm{~K}_{2} \mathrm{O}$ & 0.02 & 0.04 & 0.04 & 0.05 & 0.05 \\
$\mathrm{Total}^{\mathrm{O}}$ & 99.31 & 99.74 & 99.23 & 98.67 & 98.55 \\
$\mathrm{Ab}$ & 18.7 & 20.8 & 22.2 & 32.3 & 36.1 \\
$\mathrm{An}$ & 81.2 & 79.0 & 77.5 & 67.4 & 63.6 \\
$\mathrm{Or}$ & 0.1 & 0.2 & 0.2 & 0.3 & 0.3 \\
\hline
\end{tabular}

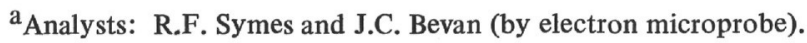

$b_{\text {n.d. }}=$ not determined.

TABLE 12

Plagioclase Feldspar Analyses, Sample 319A-7-1, 121-124 cm

\begin{tabular}{|c|c|c|c|}
\hline & Phenocryst & Groundmass & $\begin{array}{l}\text { Groundmass } \\
\text { (av. of 3) }\end{array}$ \\
\hline $\mathrm{SiO}_{2}$ & 51.76 & 49.49 & 52.16 \\
\hline $\mathrm{Al}_{2} \mathrm{O}_{3}$ & 30.09 & 31.50 & 28.81 \\
\hline $\mathrm{FeO}^{*}$ & 0.60 & n.d. ${ }^{b}$ & n.d. ${ }^{b}$ \\
\hline $\mathrm{MgO}$ & 0.25 & n.d. ${ }^{b}$ & n.d. ${ }^{b}$ \\
\hline $\mathrm{CaO}$ & 14.11 & 15.71 & 13.52 \\
\hline $\mathrm{Na}_{2} \mathrm{O}$ & 3.58 & 2.20 & 3.78 \\
\hline $\mathrm{K}_{2} \mathrm{O}$ & 0.05 & 0.02 & 0.06 \\
\hline Total & 100.44 & 98.92 & 98.33 \\
\hline $\mathrm{Ab}$ & 31.4 & 20.2 & 33.5 \\
\hline An & 68.3 & 79.7 & 66.2 \\
\hline Or & 0.3 & 0.1 & 0.3 \\
\hline
\end{tabular}

${ }^{a}$ Analysts: R.F. Symes and J.C. Bevan (by electron microprobe). $\mathrm{b}_{\mathrm{n.d} .}=$ not determined. 
TABLE 13

Plagioclase Feldspar Analyses, Sample 320B-3-1, 54-57 cm

\begin{tabular}{|c|c|c|c|c|c|}
\hline & \multicolumn{2}{|c|}{ Phenocryst } & \multicolumn{2}{|c|}{ Small Phenocryst } & \multirow[b]{2}{*}{$\begin{array}{l}\text { Groundmas } \\
\text { (av. of 2) }\end{array}$} \\
\hline & Core & Rim & $\begin{array}{c}\text { Core } \\
\text { (av. of } 4 \text { ) }\end{array}$ & Rim & \\
\hline $\mathrm{SiO}_{2}$ & 50.91 & 52.17 & 51.72 & 53.86 & 51.81 \\
\hline $\mathrm{Al}_{2} \mathrm{O}_{3}$ & 31.08 & 29.86 & 30.06 & 27.82 & 29.99 \\
\hline $\mathrm{FeO}^{*}$ & 0.52 & n.d. ${ }^{b}$ & 0.62 & n.d. ${ }^{b}$ & n.d. ${ }^{\mathrm{b}}$ \\
\hline $\mathrm{MgO}$ & n.d. ${ }^{b}$ & n.d. ${ }^{b}$ & n.d. ${ }^{b}$ & n.d. ${ }^{b}$ & n.d. ${ }^{b}$ \\
\hline $\mathrm{CaO}$ & 15.49 & 14.36 & 14.48 & 13.09 & 14.43 \\
\hline $\mathrm{Na}_{2} \mathrm{O}$ & 3.17 & 3.69 & 3.50 & 4.11 & 3.47 \\
\hline $\mathrm{K}_{2} \mathrm{O}$ & 0.05 & 0.06 & 0.05 & 0.06 & 0.05 \\
\hline Total & 101.22 & 100.14 & 100.43 & 98.94 & 99.75 \\
\hline$A b$ & 27.0 & 31.6 & 30.3 & 36.1 & 30.2 \\
\hline$A n$ & 72.7 & 68.0 & 69.4 & 63.6 & 69.5 \\
\hline $\mathrm{Or}$ & 0.3 & 0.3 & 0.3 & 0.3 & 0.3 \\
\hline
\end{tabular}

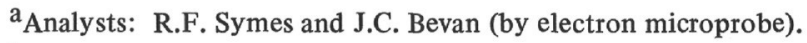
$\mathbf{b}_{\text {n.d. }}=$ not determined.
TABLE 14

Plagioclase Feldspar Analyses, Sample 321-14-4, 7-10 cm

\begin{tabular}{|c|c|c|c|c|c|}
\hline & \multicolumn{2}{|c|}{ Phenocryst } & \multicolumn{2}{|c|}{ Phenocryst } & \multirow[b]{2}{*}{ Groundmass } \\
\hline & $\begin{array}{c}\text { Core } \\
\text { (av. of 2) }\end{array}$ & $\underset{\text { (av. of 2) }}{\operatorname{Rim}}$ & $\begin{array}{c}\text { Core } \\
\text { (av. of 3) }\end{array}$ & Rim & \\
\hline $\mathrm{SiO}_{2}$ & 51.76 & 52.59 & 52.88 & 53.49 & 52.75 \\
\hline $\mathrm{Al}_{2} \mathrm{O}_{3}$ & 29.15 & 29.08 & 28.16 & 27.69 & 28.87 \\
\hline $\mathrm{FeO}^{*}$ & 0.74 & n.d. ${ }^{b}$ & 0.72 & n.d. ${ }^{b}$ & n.d. ${ }^{b}$ \\
\hline $\mathrm{MgO}$ & 0.16 & n.d. ${ }^{b}$ & 0.20 & n.d. ${ }^{b}$ & n.d. ${ }^{b}$ \\
\hline $\mathrm{CaO}$ & 14.25 & 12.95 & 13.14 & 11.89 & 12.63 \\
\hline $\mathrm{Na}_{2} \mathrm{O}$ & 3.48 & 3.96 & 4.06 & 4.95 & 4.48 \\
\hline $\mathrm{K}_{2} \mathrm{O}$ & 0.07 & 0.07 & 0.07 & 0.06 & 0.07 \\
\hline Total & 99.61 & 98.65 & 99.23 & 98.08 & 98.80 \\
\hline $\mathrm{Ab}$ & 30.6 & 35.5 & 35.7 & 42.8 & 39.0 \\
\hline An & 69.0 & 64.1 & 63.9 & 56.9 & 60.6 \\
\hline Or & 0.4 & 0.4 & 0.4 & 0.3 & 0.4 \\
\hline
\end{tabular}

aAnalysts: R.F. Symes and J.C. Bevan (by electron microprobe). $\mathrm{b}_{\text {n.d. }}=$ not determined.

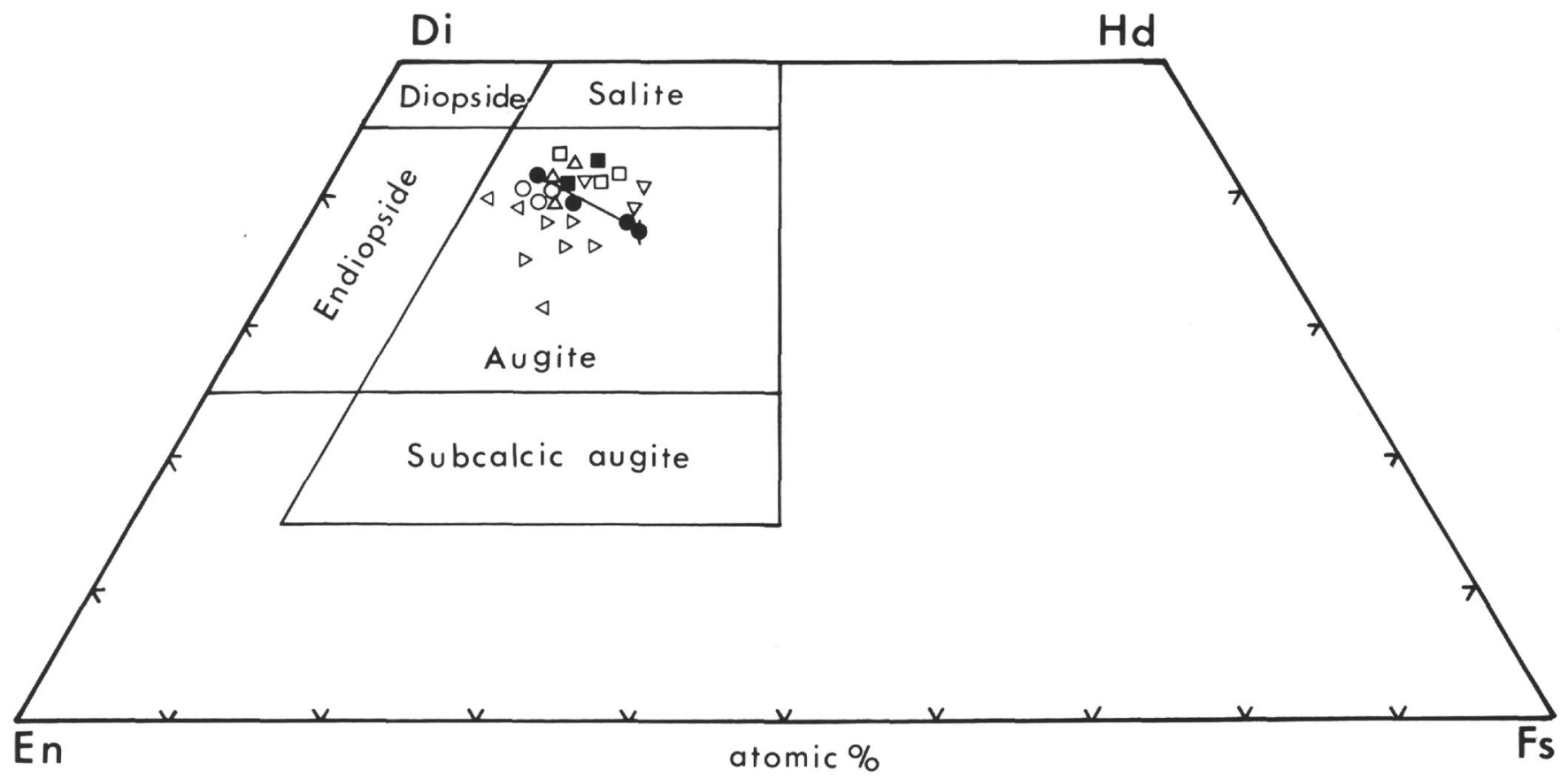

Figure 11. Pyroxene compositions from the Leg 34 basalts from Sites 319, 320, and 321. ロ $\square$ 319A-2-1; • 0 319A-3-1; $\triangle$ $319 A-5-1 ; \nabla 319 A-7-1 ; \triangleleft 320 B-3-1 ; \triangle 321-14-4$; Solid symbols, phenocryst, or phenocryst core $\phi$ phenocryst rim, joined to core with tie line; Open symbols, groundmass. 

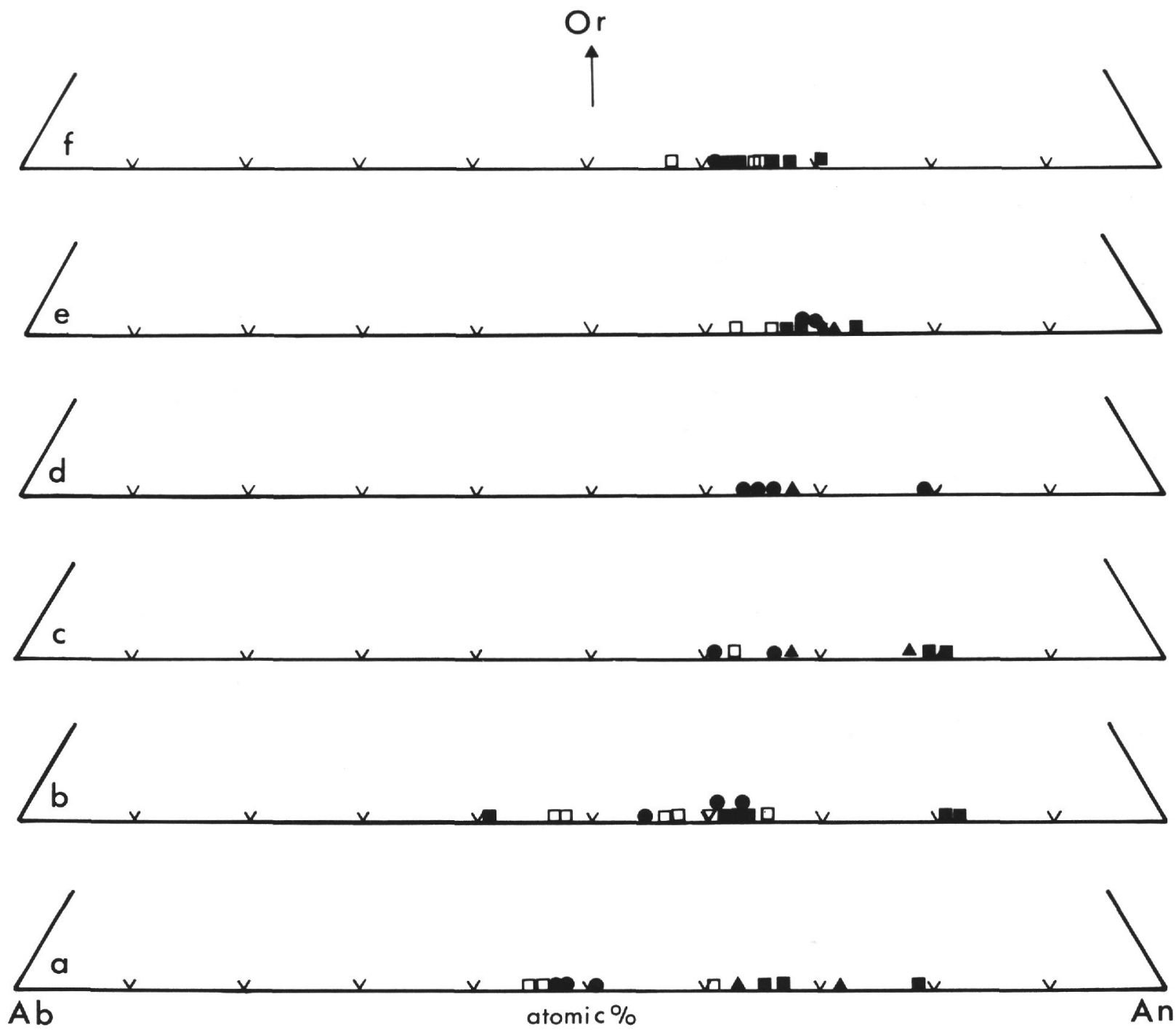

Figure 12. Plagioclase feldspar compositions from the Leg 34 basalts from (a) $319 A-2-1$; (b) $319 A-3-1$; (c) $319 A$ 5-1; (d) 319A-7-1; (e) 320B-3-1; and (f) 321-14-4. - phenocryst core; $\square$ phenocryst rim; 4 phenocryst; • groundmass lath; "inclusion" in phenocryst from 319A-3-1; $\square$ in (c) represents the least calcic limit of zoning and not a precise analysis.

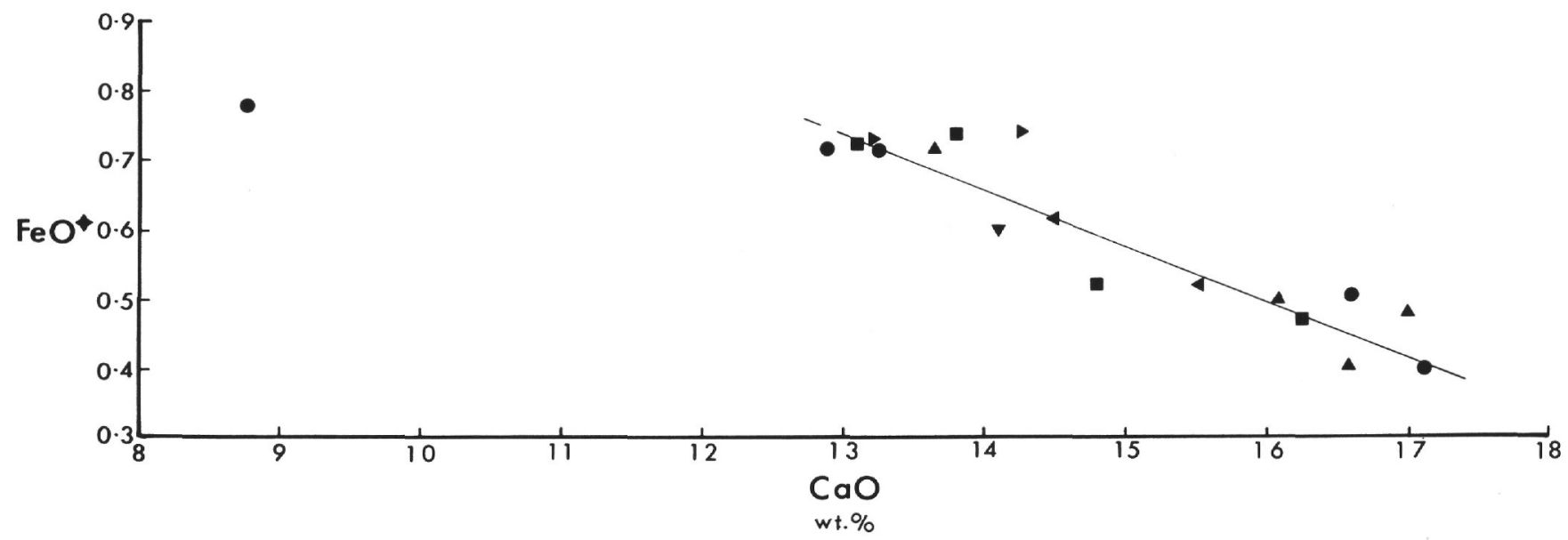

Figure 13. $\mathrm{FeO}$ * plotted against $\mathrm{CaO}($ wt\%) in plagioclase phenocrysts from Site $319 A:-319 A-2-1, \bullet 319 A-3-1, \triangle 319 A-5-1$, $\nabla 319 A-7-1,4320 B-3-1 ; \mathbf{4} 321-14-4$. 



\section{PLATE 1}

Figure 1 Photomicrograph of variolitic basalt, Bauer Deep (319-13-1, 77-80 cm). Plane polarized light ( $\mathrm{ppl})$, $\times 14$.

Figure 2 Photomicrograph of coarse variolitic basalt (319A-2-1, 111-114 cm). Note zoned plagioclase phenocryst and large pyroxene grains. This rock contains a few grains of celadonite. Crossed polars, $\times 14$.

Figure 3 Photomicrograph of ophitic basalt (319A-3-1, 78$81 \mathrm{~cm})$. Note embayed plagioclase laths, apparently formed around preexisting pyroxene, and "runic" texture within the sheaves of pyroxene crystals. Ppl, $\times 14$.

Figure 4 Photomicrograph of subophitic basalt, with some phenocrysts (319A-3-5, 75-78 cm). Note small phenocrysts of olivine completely altered to smectite. Crossed polars, $\times 14$.

Figure 5 Photomicrograph of porphyritic, hyaloophitic basalt (319A-5-1, 20-22 cm). Note plagioclase phenocrysts, altered olivine, and glassy "pools." Crossed polars, $\times 14$.

Figure 6 Photomicrograph of glassy basalt (319A-6-1, 93$98 \mathrm{~cm})$. This rock contains very small fresh olivines. Ppl, $\times 14$. 

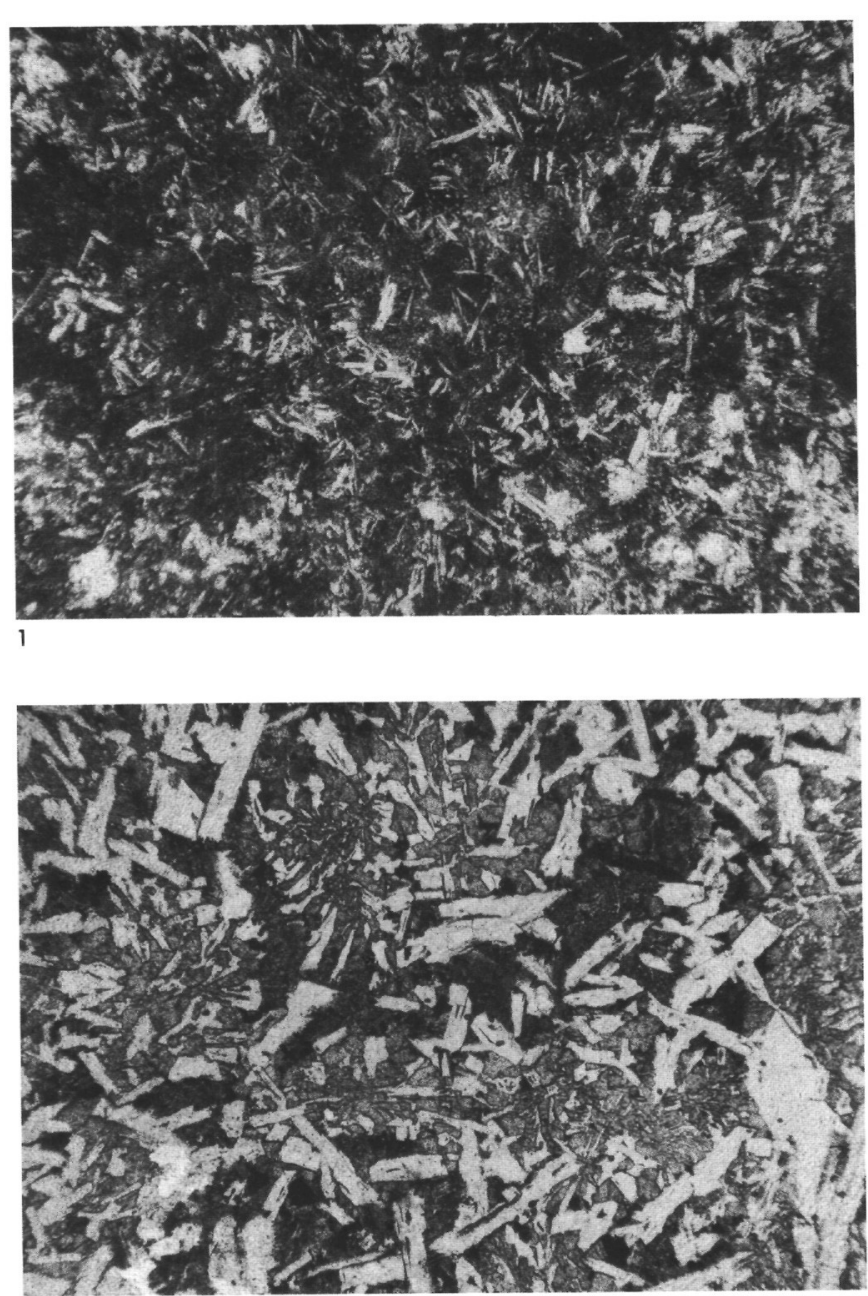

3

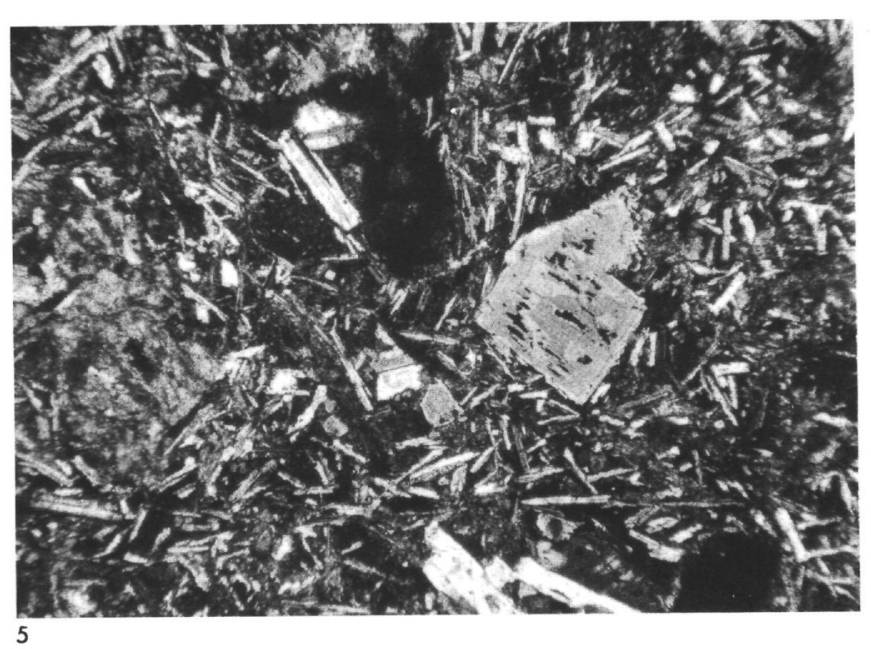

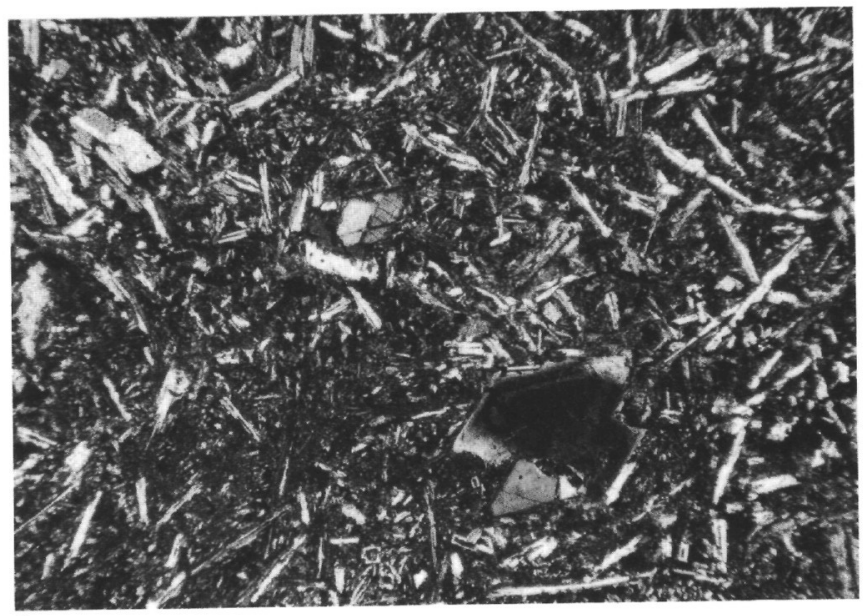

2

Fivon.

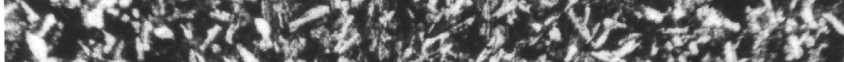

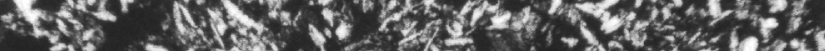

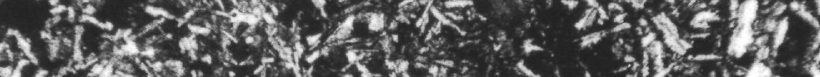
4.2.

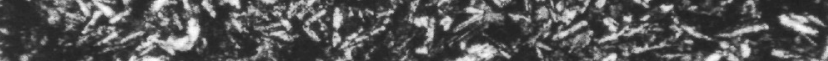

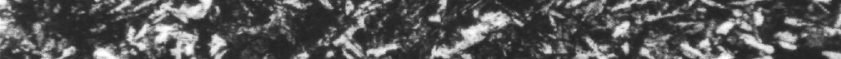

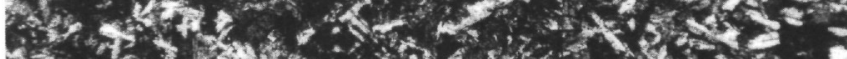

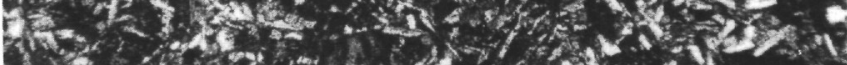

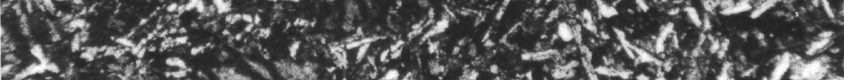

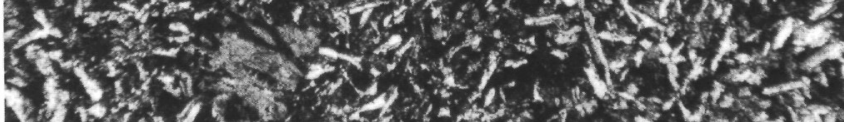

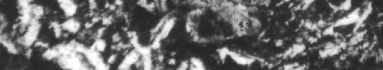

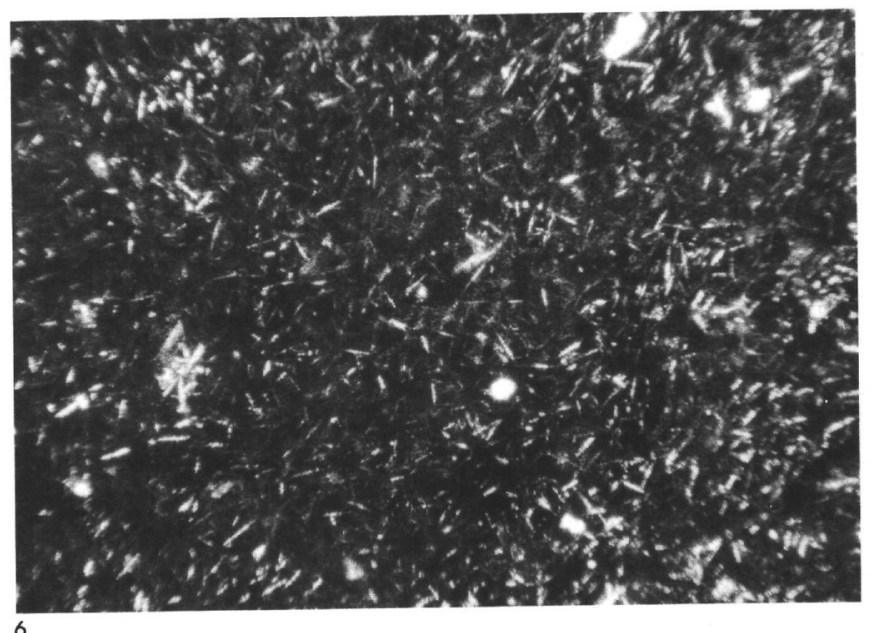




\section{PLATE 2}

Figure 1 Photomicrograph of porphyritic subvariolitic basalt (319A-7-1, 121-124 cm). Note large $(2 \mathrm{~mm})$ phenocryst of olivine, not entirely altered to smectite, and small plagioclase phenocryst. Ppl, $\times 14$.

Figure 2 Photomicrograph of porphyritic variolitic basalt from the eastern margin of the Nazca plate (320B3-1, 54-57 cm). Note small phenocrysts and bifurcate microlites of plagioclase. Ppl, $\times 14$.

Figure 3 Photomicrograph of variolitic basalt (320B-5, $\mathrm{CC})$. Note plumose or feathery pyroxene microlites. Ppl, $\times 14$.

Figure 4 Photomicrograph of vesicular hyaloophitic basalt (321-14-1, 42-45 cm). Most of the vesicles are empty. The texture in the "islands" is fine grained subophitic, with many embayed plagioclase crystals. $\mathrm{Ppl}, \times 14$.

Figure 5 Photomicrograph of vesicular hyaloophitic basalt $(321-14-2,9-12 \mathrm{~cm})$. The vesicles are filled with calcite. Ppl, $\times 14$.

Figure 6 Photomicrograph of coarse hyaloophitic, subophitic basalt (321-14-4, 7-10 cm). Note microphenocrystic laths of plagioclase and embayed feldspar grains clustered with pyroxene. Crossed polars, $\times 14$. 

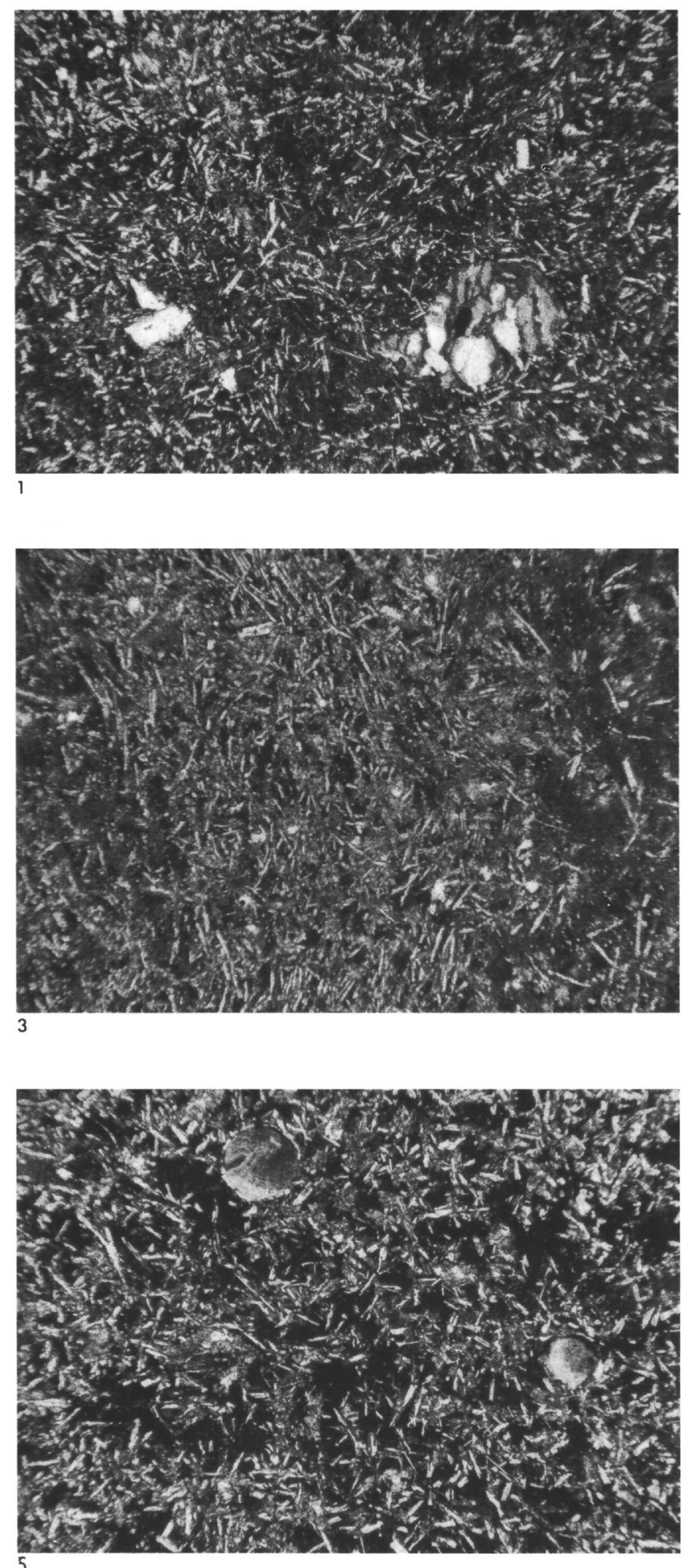
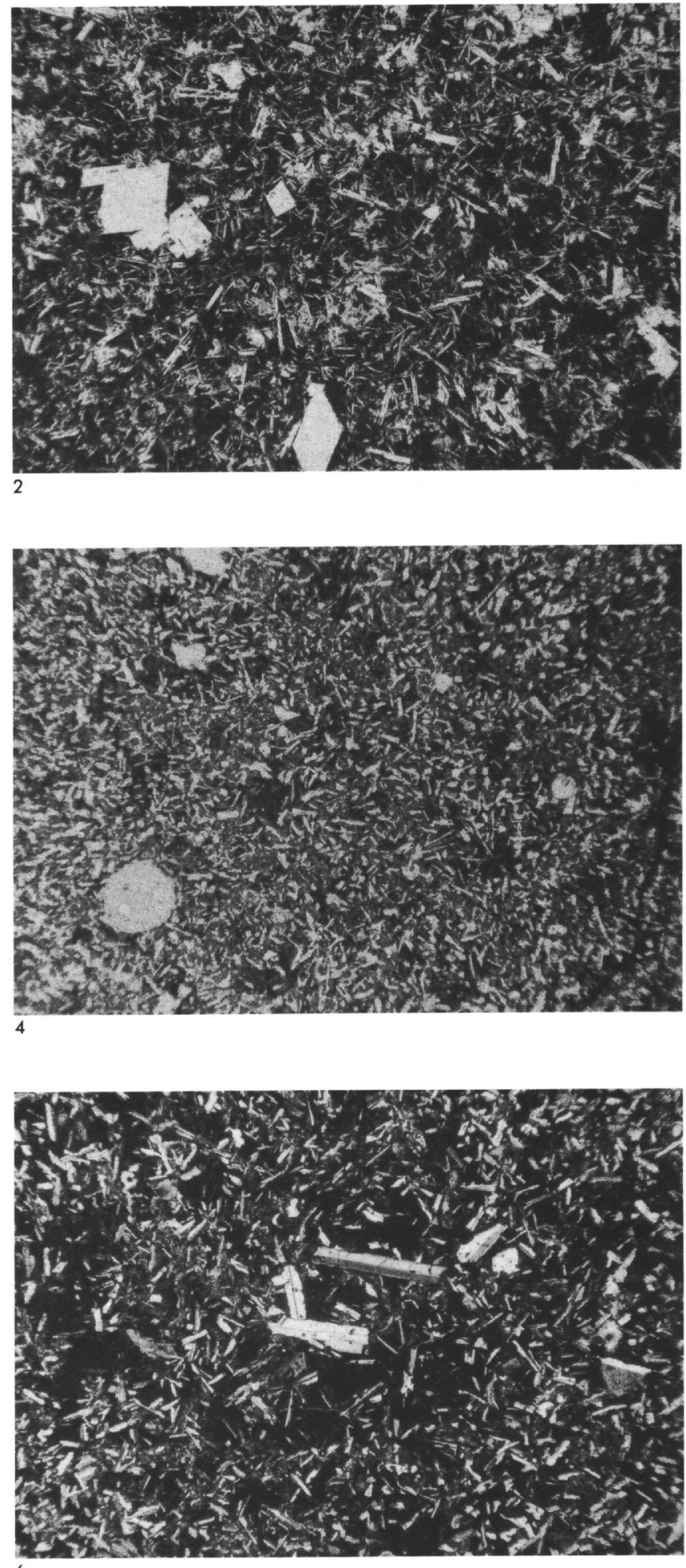